\title{
Does familiarity with business segments affect CEOs' divestment decisions?*
}

\author{
James Ang \\ College of Business \\ Florida State University \\ e-mail: jang@cob.fsu.edu \\ Abe de Jong ${ }^{+}$ \\ Rotterdam School of Management \\ Erasmus University \\ e-mail: ajong@rsm.nl \\ Marieke van der Poel \\ Rotterdam School of Management \\ Erasmus University \\ e-mail: $\underline{\text { mpoel@ } @ \text { rsm.nl }}$
}

August 2013

\footnotetext{
*We are grateful to Malcolm Baker, Guillermo Baquero, John Doukas, Marie Dutordoir, Denys Glushkov, Nancy Huyghebaert, Ulrike Malmendier, Gerard Mertens, Peter Roosenboom, Len Rosenthal, Frederik Schlingemann, Jack Stecher, Jeroen Suijs, Mathijs van Dijk, an anonymous reviewer, participants at the 2005 ERIM Conference Financial Management Track, participants at the 2006 EFMA conference (Madrid), participants at the 2007 EFA conference (New Orleans), participants at the 2007 EFA conference (Ljubljana), participants at the 2007 FMA conference (Orlando), seminar participants at RSM Erasmus University, at the University of Antwerp, at the Norwegian School of Economics and Business Administration, at the Catholic University of Leuven, at Florida State University, and at Tilburg University for providing helpful comments and suggestions. We are also grateful to the Vereniging Trust Fonds for providing financial support and to John Simon for excellent editing.

${ }^{+}$Corresponding author: Department of Finance (Room T09-55), RSM Erasmus University, PO Box 1738 , 3000 DR Rotterdam, The Netherlands; Phone: +31 10408 1022; Fax: +31 104089017
} 


\title{
Does familiarity with business segments affect CEOs' divestment decisions?
}

\begin{abstract}

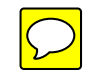

We examine the impact of familiarity with business segments on CEOs' divestment decisions. We find CEOs to be less likely to divest assets from familiar than from non-familiar segments. We attribute this effect to CEOs' comparative information advantage relative to familiar segments. Reflecting this information advantage, we document the familiarity effect to be particularly strong in R\&D intensive industries. We further find the familiarity effect to be most pronounced for longer-tenured CEOs who have built up sufficient political power over the course of several years in office to enable implementation of their preferred choices. We also document the value effects of divestments and show familiarity to affect returns on divestment announcements.
\end{abstract}

Keywords: Divestments; Familiarity; CEO work experience; CEO selection 


\section{Introduction}

Corporate divestment decisions translate into major business restructurings. We examine here whether CEOs' career paths affect their divestment decisions. Recent research in corporate finance has found managerial characteristics to play an important role in investment, financial, and strategic decisions (e.g., Bertrand and Schoar (2003), Malmendier and Tate (2005, 2008), and Chang, Dasgupta, and Hilary (2010)), and substantial empirical evidence documents investors' and managers' preference for choosing the familiar. Investors, for example, are inclined to ignore optimal portfolio principles in order to invest in familiar companies (see, for example, French and Poterba (1991), Huberman (2001), Li (2004), and Parwada (2008)), and firms exhibit a similar geographic proximity effect in both cross-listing decisions (Sarkissian and Schill (2004)) and banking choices (Berger, Dai, Ongena, and Smith (2003)).

In this paper, we attempt to determine whether multi-segment firms' divestment decisions are affected by CEOs' familiarity with the firms' segments. Consider a firm that operates in two business segments, segment A and segment B. The CEO is familiar with segment A, having previously been employed in that segment, but not with segment B. Faced with an opportunity to divest assets from either segment, which is the CEO likely to choose? We propose two non-mutually exclusive hypotheses, one based on CEOs' better information about familiar segments, the other on CEOs' political power in a firm.

The first hypothesis, labeled the comparative information hypothesis, predicts that CEOs are less likely to divest assets from segments familiar to them. The intuition behind this hypothesis is that CEOs' work experience provides a comparative information advantage with respect to familiar relative to nonfamiliar segments. CEOs prefer to manage familiar segments because an understanding of a segment's business enhances the confidence in assessments of the quality of investment opportunities (Miao and Sandford (2013)). Owing to agency problems between CEOs and division managers (e.g., Milgrom and Roberts (1988), Jensen (2003), and Wulf (2009)), CEOs' information advantage with respect to familiar segments can affect firms' budget allocations. Divestments in this setting can be viewed as negative budget allocations in internal capital markets in which CEOs often depend on segment managers' private information about future cash flows. Although segment managers are prone to overstate their case in order to secure a greater allocation of the budget (or avoid divestment), CEOs tend to more greatly discount requests of segment managers who possess more private information (Harris and Raviv (1996, 1998); Bernando, Cai, and Luo (2001)), which is the case for segments with which a CEO is not familiar.

We postulate two reasons for the familiarity effect's persistence over time, (1) CEOs' comparative information advantage with respect to, stemming from their deeper knowledge of, familiar segments, and (2) sharing information with managers of familiar segments reduces CEOs' costs of information acquisition and verification. Because having a common background (Gaspar and Massa (2011)) and being connected (Duchin and Sosyura (2013)) foster more personal interaction and a higher 
level of trust, more information tends to be shared with, and more capital allocated to, managers of segments with which CEOs share a common background (Gaspar and Massa (2011)) and to whom they are connected (Duchin and Sosyura (2013)). In our setting, CEOs and managers of familiar segments have worked in the same segment and, if they did so during the same time period, are likely to be connected. Their common background knowledge leads them to keep each other informed about segmentrelated issues, and the mutual trust they share to keep such exchanges truthful. We are thus led to expect CEOs' preference for divesting non-familiar segments over the course of their tenure.

The second hypothesis, which we term the political power hypothesis, predicts that the preference for divesting non-familiar segments is contingent on CEOs commanding sufficient political power to carry out their preferred choices. Multi-division firms' internal capital markets' capital allocation processes can be disrupted by valuable private information and internal political clout providing segment managers bargaining power over CEOs (Stein (2003)). The bargaining power of managers of non-familiar segments derives from CEOs' dependence on such managers' valuable knowledge and support. Xuan (2009) argues that susceptibility to the bargaining power of managers of non-familiar segments is strongest in CEOs new to the job, and provides evidence that such CEOs find it expedient to promote goodwill towards managers of, by increasing investment in, non-familiar segments. We therefore expect the motivation to build political capital with managers to lead new CEOs to refrain from divesting assets from non-familiar segments until such time as they accumulate sufficient political power to act according to their preferences.

Analysis of business segments of divesting multi-segment firms yields evidence consistent with both hypotheses. In line with the comparative information hypothesis, we find that CEOs divest familiar segments (also referred to as direct-experience segments, i.e., segments in which CEOs worked before being promoted to their current positions) $39 \%$ less often than non-familiar segments. In line with the political power hypothesis, we observe the familiarity effect overwhelmingly in the subsample of established (i.e., with tenure of three years or more) over newly hired CEOs. Refining the political power test for the subset of newly hired CEOs by differentiating between those to whom internal political capital has accrued by virtue of previously holding the corporate executive-level position of chief operating officer (COO) and those for whom this is not the case, we find less powerful new CEOs to act contrary to their preference in being more likely to divest assets from familiar segments. This finding complements Xuan's (2009) finding that less powerful new CEOs attempt to build rapport with their managers by increasing capital allocations to non-familiar segments. We do not observe this behavior in more powerful new CEOs.

By way of additional evidence for the comparative information hypothesis, we first add to our test another dimension of familiarity based on industry experience within the firm. Segments familiar by 
virtue of CEO experience in another segment operating in the same industry as the direct-experience segment (referred to as industry-experience segments) are the basis of a shared background with the managers of segments about which CEOs are knowledgeable, albeit not as knowledgeable as about their direct-experience segments. If superior information plays an important role in selecting segments to be divested, CEOs with sufficient internal political clout may be reluctant to divest assets from industryexperience segments. Our results support this conjecture. Although the familiarity effect is stronger for direct-experience than for industry-experience segments, we find established CEOs to be less likely to divest assets from the latter than from non-familiar segments.

Our second additional test of the comparative information hypothesis accounts for the required deeper understanding of industries in which segments operate, as proxied by R\&D intensity. Retaining familiar segments is beneficial owing to the prospect of $R \& D$ investments, being based on soft information that is typically difficult to transmit in an impersonal way, ${ }^{1}$ being mostly uncertain and difficult to accurately assess (Miao and Sandford (2013)). That the degree of information asymmetry between segment managers and CEOs escalates with level of R\&D intensity constitutes an incentive for managers to misrepresent their segments' prospects, to which CEOs respond by more greatly discounting the capital allocated to those segments (e.g., Bernardo, Cai, and Luo (2001)), which can take the form of divestment. Familiarity with a segment can overcome these information problems. The greater frequency with which CEOs and managers of familiar segments personally interact affords more opportunities to share soft information and a deeper level of trust that may be expected to enhance the quality of the shared information. Because CEOs and managers of non-familiar segments do not share this understanding, we expect the familiarity effect to be most pronounced for familiar segments that operate in R\&D intensive industries. Our findings are in line with this conjecture.

Our final analysis is an event study around divestment announcements to measure the value effects of familiarity. Consistent with their superior information with respect to direct-experience segments, we find CEOs' divestments of these segments to generate $1.2 \%$ higher abnormal returns. Remarkably, the greater returns are particularly pronounced for divestments of direct-experience segments by longer-tenured CEOs in firms with low R\&D intensity. We attribute our finding in this subsample of a $2.4 \%$ higher abnormal return upon announcement to the information disadvantage of the stock market and acquirer of the assets, which is much smaller in low R\&D intensive industries.

The familiarity effect on divestment decisions is robust to four alternate explanations. We refute first the explanation that boards select CEOs with work experience specific to a particular business segment that is to be grown and focused upon as part of firm strategy. The effects of board mandates to

\footnotetext{
${ }^{1}$ See Petersen (2004) for a discussion of the use of hard and soft information.
} 
grow direct-experience segments should be particularly strong in a CEOs' first years of tenure, which is the subset for which we do not find a familiarity effect. We further find that in the year prior to CEO appointment, the ex ante predicted probability of divesting assets is higher rather than lower for directexperience segments relative to other segments. Were we to credit the second alternative explanation of selection effects, internal promotion criteria, whereby CEOs are more likely to be promoted from well performing segments, which are also the segments least likely to be divested, we would expect (1) the familiarity effect to be observed most frequently early in a CEO's tenure, (2) direct-experience segments of firms managed by new CEOs to outperform non-familiar segments, and (3) the ex ante predicted probability of a segment being divested to be higher. We find no evidence to support any of these expectations. The third alternative explanation for the familiarity effect is CEO entrenchment (Shleifer and Vishny (1989)), specifically, that CEOs would divest assets from non-familiar segments to increase the proportion of assets that complement their skills. Accounting for governance mechanisms, we find no support for this explanation. Finally, if a CEO's direct experience in a segment were to proxy for the segment being core, our documented familiarity effect might merely reflect a firm's decision to focus on its core business. Our finding that CEOs tend to be particularly reluctant to divest assets from non-core direct-experience segments contradicts this explanation.

Our main contribution in this paper is to demonstrate significant effects of CEOs' professional career paths on corporate strategy and value. We show divestment decisions observed in a multi-segment firm to depend on two factors. CEO familiarity with a segment affords knowledge that results in less discounting of the segment manager's claims, but implementation of preferred divestment choices hinges on possession of adequate political clout with top managers.

Our paper adds to the stream of literature on capital allocation decisions (see, for a review, Stein (2003) and Maksimovic and Philips (2007)). Furthermore, Weisbach's (1995) classic paper argues that CEOs are least likely, shortly after being appointed, to divest assets that represent their skill sets. This paper differs from ours in that Weisbach (1995) does not directly examine CEO characteristics; the divestments in his sample are all assets acquired under previous CEOs, and he focuses on newly appointed CEOs. The study most directly related to ours is Xuan (2009), which yields parallel results in its finding that new CEOs deem it expedient to favor non-familiar segments during their first two years of tenure. Extending our analysis beyond two years reveals CEOs' preference for familiar segments to be manifested when they become more established. Another related paper, Huang (2010), suggests that CEOs attempt to improve firm performance by divesting entire segments that operate in industries in which they lack work experience in pursuit of a better match between their skill set and new firm. We posit two interpretations of skill set, one being the skills to operate a segment, the other the skill or knowledge requisite to more deeply understanding a segment's value and potential. Although both papers 
examine a familiarity effect, our hypothesis is developed on a more comprehensive foundation that takes into account the application of superior information to divestment decisions.

Our paper also contributes to studies of executive career paths that distinguish between generalist and specialist CEOs. Murphy and Zabojnik (2004), for example, find general management skills to be more important than firm-specific experience and skills as a determinant of CEO pay. Because bargaining power in the labor market may explain this effect, Custódio, Ferreira, and Matos (2013) investigate the composition of CEOs' general skills, and document a trend towards more generalist CEOs who earn a premium in pay, particularly during restructurings and acquisitions. That a CEO familiar with a particular segment can be both a specialist and a generalist engenders the interesting question of whether our result is stronger for either type of CEO. Exploring this question in the case of divestment decisions, we find no difference in the familiarity effect between generalist and specialist CEOs.

Finally, our paper complements the paper of Landier, Nair, and Wulf (2009), who examine the effect on corporate decisions of geographic location, specifically, the proximity of a segment to its headquarters (specifically, whether a segment and headquarters are in the same state). Our study measures social distance, that is, CEOs' personal ties to segments. Landier, Nair, and Wulf's (2009) finding that CEOs are less likely to divest divisions and lay off employees of divisions more proximate to headquarters, and that information constraints explain why CEOs favor more proximate employees, complements our information explanation.

The paper is organized as follows. In Section 2, we outline the set-up of our empirical analysis. Results of our tests of the comparative information and political power hypotheses are presented in Section 3. We investigate three alternative explanations of the familiarity effect in Section 4, and describe the valuation effects of familiarity in Section 5. Section 6 concludes.

\section{Does CEO familiarity affect divestment decisions?}

\subsection{Sample and data sources}

We construct our initial sample from the Compustat Business Information File and Securities Data Corporation (SDC) file. We select data for firms with at least two business (or operating) segments for our sample period of 1996-2004. As in Schlingemann, Stulz, and Walkling (2002), we select firms with sales in excess of $\$ 20$ million or assets exceeding $\$ 100$ million. We exclude American Depository Receipts (ADRs) and firms not incorporated in the United States as well as firm years with segments that operate in regulated industries (SIC 4900 - 4999). Like Berger and Ofek (1995) and Schlingemann, Stulz, and Walkling (2002), we require that the sum of segment sales not deviate more than $1 \%$ from total firm sales. These selection criteria result in a sample of 5,251 firm years for 1,009 firms for our sample period. 
Selecting from the SDC database for all divestments completed during the 1996-2004 period by the 1,009 multi-segment firms yields 1,317 firm years (530 firms) with divestments. Similar to Xuan (2009, p. 4921), we measure divestments at the level of segments and use the terms segment and division interchangeably. Segments or divisions may consist of several business units, and firms can divest an entire division or one or more business units. We require (as in McNeil and Moore (2005)) that more than $95 \%$ of a unit's assets be acquired by the buying firm post transaction. We manually link divested business units with the business segments reported in Compustat using the SDC divestment synopses, SDC SIC codes, and SDC business descriptions of divested assets. Additionally, we search SEC 10-K filings for descriptions of segments and discontinued operations. The unit of observation in our main analysis being a segment in a given year, we treat multiple divestments within one segment year as a single segment observation. ${ }^{2}$

We require segments to have at least two years of data prior to divestment. During our sample period, which includes the introduction of SFAS 131 in 1997, several firms changed their segment reporting (see Berger and Hann $(2003,2007)$ ). ${ }^{3}$ Compustat provides revised historical financial information for new segments for the two years prior to reporting based on firms' annual reports. We exclude 589 firm years from 192 firms due to incomplete Compustat historical data.

We require for our familiarity variables detailed information about CEOs' work experience, for which we turn to the Marquis Who's Who and Hoover's databases, which provide summaries of top executives' previous positions. We focus on the segments within CEOs' firms to measure experience and do not distinguish levels of previous positions. For CEOs whose careers we cannot reconstruct from these sources, we consult SEC 10-K and proxy filings. In the event these sources lack sufficient data, we exclude the observation (in total, we exclude, for this reason, 49 firm years for 21 firms). Although we acknowledge that, owing to the imperfection of these sources, we may miss an executive's prior experience, this would lead to a bias against finding economically and statistically significant effects for variables based on experience.

We exclude as well 71 firm years (15 firms) for reasons of firms having two CEOs, classifications of divestments being ambiguous, or divestments occurring in corporate segments in which firms divested assets acquired from a merger in the previous year. This selection procedure yields 608

\footnotetext{
${ }^{2}$ If multiple divestments occur in different segments, we classify more than one segment within one firm year as a divesting segment.

${ }^{3}$ Under SFAS 131 firms do not always report segments based on industry; they can also report their segments based on vertical integration. We believe that this change in segment reporting does not affect our conclusions. If anything, it would add noise to our analyses, and hence work against our finding significant results.
} 
firm years with 2,394 segment years. Further excluding 393 segment years with incomplete corporate financial information, or that are tagged as "elimination" (as in Lamont (1997)), leaves 2,001 segment years.

We are interested in whether their level of familiarity with segments affects CEOs' selections of which to divest, and a preference for one segment over another based on familiarity can be exhibited only when a CEO has a choice between familiar and non-familiar segments, which is to say, when levels of familiarity differ within a firm year. We therefore exclude 342 firm years in which CEOs lack direct work experience in any segment (the case of external CEOs, who by definition cannot have direct work experience in a segment) or only have experience overseeing all segments (as the case of founders). ${ }^{4}$ Our final sample includes 923 segment years (352 of which experience a divestment and 571 of which are fully retained), 266 firm years, 121 firms, and 134 CEOs.

\subsection{Familiarity measure}

We construct at the segment level two proxy variables for familiarity that differentiate the two levels of relevant work experience prior to being appointed CEO. Because understanding our measures is crucial to our analysis, we illustrate the definitions with an example. In fiscal year 1998, Bausch \& Lomb disclosed four segments: Vision Care (two-digit SIC 28 and 38), Eyewear (two-digit SIC 38), Pharmaceuticals (two-digit SIC 28), and Healthcare (two-digit SIC 2 and 28). William Carpenter, Bausch \& Lomb Inc.'s CEO in 1998, had been global business manager in the company's Eyewear segment from when he joined the firm in March 1995 until December 1995.

Our first measure, the strongest form of familiarity, is direct work experience within a segment. We therefore classify Bausch \& Lomb's Eyewear segment, of which Carpenter was global business manager, as the segment in which he has direct work experience. This level of familiarity implies knowledge of a segment's industry and internal operations as well as direct personal relations with its personnel and management.

\footnotetext{
${ }^{4}$ The 342 excluded firm years consist of 61 firm years with founders (including CEOs who started as executive officers subsequent to a spin-off), 136 firm years with external hires (who cannot have direct-experience segments), 14 firm years with internal hires and all segments direct-experience segments, and 131 firm years with internal hires without any familiar segments. Instead of deleting those firm years, we could add an interaction term between firm years with variation in familiarity and the different familiarity measures and use the entire sample of 608 firms. Our conclusions hold when we perform the analysis thus. However, because we use logit regressions for which the interpretation of interaction coefficients is not trivial (e.g., Ai and Norton (2003)), we decided to exclude those 342 observations from our analyses.
} 
Industry work experience refers to experience gained working in a segment that operated in the same two-digit SIC industry as the reported segment. In our example, industry work experience in the Vision Care segment is attributed to Carpenter because it operates in the same two-digit industry (SIC 38) as the Eyewear segment of which he was global business manager.

Industry work experience, because it implies less likelihood of having personal connections and specific knowledge of assets, procedures, and developments within reported segments, is inferior to direct work experience in terms of level of familiarity. We term "non-familiar segments" those in which CEOs have neither direct nor industry work experience. We treat classifications of CEO familiarity with individual segments as mutually exclusive, where the segments are assigned to the stronger of the two forms of familiarity. In our example, this means that we classify Eyewear as a direct work experience segment, Vision Care as an industry work experience segment, and Pharmaceuticals and Healthcare as non-familiar segments.

\subsection{Control variables}

To examine the type of segment selected for divestment, we include a number of control variables. For each business segment we obtain from the Compustat Business Information File sales, assets, net capital expenditures (calculated as gross capital expenditures minus depreciation and amortization), cash flows (calculated as operating profit plus depreciation and amortization), and primary and secondary SIC codes, ${ }^{5}$ and from the Annual Compustat File, segment industry-adjusted measures and variables for calculating Tobin's $q$ as well as firm-level financial variables and primary SIC code. We obtain governance information from the IRRC and share price information from CRSP.

We classify as core the largest segment in a firm in terms of reported sales that has the same primary two-digit SIC code as the firm. To facilitate comparability, we follow Schlingemann, Stulz, and Walkling (2002) in calculating industry measures as the median of all Compustat firms with the same two-digit SIC code in the fiscal year prior to the divestment announcement. To ensure reliability, we require that at least five firms operate in the same industry. A segment's Tobin's $q$ is the industry ratio of the market value of assets to the book value of assets, for which we use variables similar to those employed by Malmendier and Tate $(2005,2008) .{ }^{6}$ We use SALE to calculate median industry sales, OIBDP to calculate median industry cash flows, and CAPX and DP to calculate median industry net

\footnotetext{
${ }^{5}$ We follow the recommendation of Kahle and Walkling (1996) in using Compustat's industry classification and not that of CRSP, and using the historical industry classifications throughout our analyses.

${ }^{6}$ We calculate the market value of assets as book value of total assets (AT) plus market equity minus book equity. Market equity $=(\mathrm{CSHO} * \mathrm{PRCC})$, book equity $=($ SEQ $-\mathrm{PSTKL}+\mathrm{TXDITC}-\mathrm{PPROR})$.
} 
capital expenditures. We follow Ahn and Denis (2004) in estimating cross-subsidization as segments' industry-adjusted investment minus their firms' sales weighted sum of industry-adjusted investment, and Schlingemann, Stulz, and Walkling (2002) in calculating segment liquidity by dividing the total value of acquisition transactions by an industry's total assets, excluding from the sample values higher than one and industries with fewer than ten firms. We calculate a segment's industry R\&D intensity as the R\&D expenditures of all Compustat single-segment firms with the same two-digit SIC code weighted by the firms' beginning of year total assets. We code missing values of $R \& D$ as zero, but removing these observations from our calculations does not alter our findings. This measure requires that at least five firms operate in the same industry.

At the firm level, we calculate leverage as total debt (LT) divided by total assets (AT). ${ }^{7}$ A firm's Tobin's $q$ is the market to book value of assets, for which we use the same variables as the segment's Tobin's $q$. We calculate net capital expenditures as gross capital expenditures (CAPX) minus depreciation and amortization (DP), and use CHE for cash and short-term equivalents.

Following Berger and Ofek (1995), we calculate excess value as the percentage difference between a firm's total value and the sum of imputed values of its segments as stand-alone firms. We define excess value as equal to $\ln (\mathrm{V} / \mathrm{I}(\mathrm{V}))$, where $\mathrm{V}$ is total firm value calculated as the market value of equity (PRCC * CSHO) plus book value of debt (LT), and I(V) the imputed value of the sum of a firm's segments as stand-alone firms,

$$
I(V)=\sum_{i=1}^{n} A I_{i} *\left(\operatorname{Ind}_{i}(V / A I)_{m f}\right),
$$

where $\mathrm{AI}_{\mathrm{i}}$ is segment $i$ 's sales, $n$ the number of segments, and $\operatorname{Ind}_{\mathrm{i}}(\mathrm{V} / \mathrm{AI})_{\mathrm{mf}}$ the multiple of total capital to sales for the median single-segment firm with at least $\$ 20$ million in sales in segment $i$ 's industry. We follow Berger and Ofek (1995) and Schlingemann, Stulz, and Walkling (2002) in basing industry median ratios on the narrowest SIC grouping with at least five firms in an industry, and excluding from our sample, and considering as outliers, any values larger than 1.386 or smaller than -1.386 .

Following Rajan, Servaes, and Zingales (2000) and Schlingemann, Stulz, and Walkling (2002), we calculate a firm's diversity in $q$ as

$$
\text { Diversity }=\sqrt{\sum_{i=1}^{n}\left(\text { Sales }_{i} / \sum_{i=1}^{n} \text { Sales }_{i}\right) \times\left(q_{i}-\bar{q}\right)^{2}} / \bar{q},
$$

where $\operatorname{Sales}_{i}$ refers to segment $i$ 's sales, $n$ to the number of segments, $q_{\mathrm{i}}$ to the median $q$ of all Compustat firms with the same two-digit SIC code as segment $i$, and $\bar{q}$ to the sales-weighted average imputed $q$

\footnotetext{
${ }^{7}$ Our sample contains 15 observations in which the firm's leverage exceeds one, which is theoretically not possible. We set these values to one. Not setting these observations to one does not alter our results.
} 
across the $n$ segments of the firm. We use as a score for anti-shareholder charter provisions the entrenchment index constructed by Bebchuk, Cohen, and Ferrell (2009), in which the percentage of independent directors is the number of independent directors divided by the total number of directors.

We estimate abnormal returns to divestment announcements using the market model as described by MacKinlay (1997). Our estimation window runs from day -160 to day -41 relative to the announcement date. We aggregate abnormal returns over the day prior to until the day after the divestment announcement.

\subsection{Summary statistics}

Table 1 provides the statistics for our sample of divesting firm years.

$$
\text { - Please insert Table } 1 \text { here - }
$$

We present first the firm statistics. The sample firms have average sales of nearly $\$ 11$ billion and average assets of approximately $\$ 14$ billion. That leverage is relatively high $(65 \%)$ may be a consequence of selecting divesting firm years. Our average sample firm performs well, with positive cash flows prior to the divestment year and an average Tobin's $q$ of 1.877. The average number of segments in which the firms operate is 3.47 , and the average diversity in $q$ across segments is 0.118 . Our sample of divesting firm years' positive average excess value of 0.105 indicates that the average firm in our sample does not underperform its single-segment counterparts. The entrenchment index ranges from zero to five, with an average of 2.417, and our sample firms have, on average, $67.1 \%$ independent directors.

Panel B reports divestment statistics at the firm year level. With an annual average of 1.323 , the average divesting firm in our sample divests assets from more than one segment in a year. Only $15.4 \%$ of our divesting sample firms divests one or two full segments. Aggregating the deal value of all divested business units within a firm year, we find the value of the divested assets, on average $\$ 534$ million, to account for $10.8 \%$ of our sample firms' total assets.

Panel $\mathrm{C}$ reports CEO specific statistics. Because testing the comparative and political power hypotheses requires that all CEOs have a direct experience segment, our sample consists only of internally hired CEOs who have direct work experience in from one to four segments in a firm year. We find 59.8\% of CEOs to have industry-experience segments, average CEO age to be 56, and average term of employment with a firm to be 23.8 years and tenure as CEO 5.5 years. We further find CEOs to hold, on average, two titles (e.g., president and/or chairman as well as CEO).

Table 2 reports, in Panel A, statistics for familiar and non-familiar segments and, in Panel B, statistics for divested versus fully retained segments.

- Please insert Table 2 here - 
Panel A shows our total sample of 923 segments to consist of 588 familiar and 335 non-familiar segments. Average CEO direct work experience is 8.5 years in 354 segments and of industry experience 8.9 years in 234 segments. Our results indicate that familiar, relative to non-familiar, segments are significantly larger and more often core segments. These characteristics of familiar segments are crucial because they may induce a mechanical relation whereby a familiarity effect is driven by experience in the core segment or segment size, in the situation where boards are more likely to appoint as CEOs managers from core segments (which typically are the largest segments operating in the same industry as the firm's core industry). Although the statistics confirm that a relatively large proportion of direct-experience segments are core segments, we still have $59.6 \%$ of non-core direct-experience segments, an issue we discuss further in Section 3.1. We find familiar segments to perform significantly worse than non-familiar segments in terms of segment cash flows, although the difference is not significant after adjusting for industry-level cash flows. Familiar, relative to non-familiar, segments operate in industries that are less liquid but more R\&D intensive. Capital expenditures and industry $q$ do not differ between familiar and non-familiar segments.

Panel A shows, consistent with the comparative information hypothesis, that the percentage of divesting segments is significantly smaller for familiar than for non-familiar segments. A detailed analysis of the subsample of divesting segment years indicates that CEOs divest, on average, 1.37 business units from familiar, and 1.50 business units from non-familiar, segments. The absolute value of the aggregate transaction value of these divestments is comparable for familiar and non-familiar segments, but in relative terms, a greater, albeit not statistically significant, proportion of assets is divested from nonfamiliar segments.

Panel B shows firms to divest assets from 352 segments and fully retain 571 segments in 266 firm years. The proportion of direct-experience segments does not differ significantly between retained (36.9\%) and divested (39.2\%) segments, which result holds as well for the industry-experience segments. In contrast to the results of studies that focus exclusively on fully divested segments (e.g., Schlingemann, Stulz, and Walkling (2002) and Dittmar and Shivdasani (2003)), we show partially divested segments to be larger in terms of both absolute and relative size, indicating that they are too important to be ignored. That larger segments often consist of collections of smaller business units increases the likelihood of separable portions of segments being divested.

We also find the proportion of core segments, the largest segments in a firm year operating in the same industry as a firm's core industry, to be higher for the divested than for the retained segments sample. Although this result is counter to the motivation of divesting assets to increase the focus on firms' 
core business (John and Ofek (1995)), it is consistent with a greater likelihood of assets being divested from larger segments. ${ }^{8}$ That industry-adjusted cash flows are lower for divested than for retained segments supports two motives for divesting assets, (1) to reallocate assets to higher-valued users (Jain (1985)), and (2) to obtain funds when external financing is too expensive and internal financing insufficient (Lang, Poulsen, and Stulz (1995)).

\section{Empirical results}

\subsection{The likelihood of divesting assets from familiar segments}

We examine whether familiarity influences CEOs' decisions regarding from which segments to divest assets by estimating binary logit regressions in which the dependent variable takes the value of one for divested segments and zero for fully retained segments. We use Schlingemann, Stulz, and Walkling's (2002) specification of economic factors. We include segment performance, investment, crosssubsidization, size, and $q$, whether a segment is $\operatorname{core}^{9}$ and less than $10 \%$ of total sales, and the segment industry's liquidity. We include year dummies and dummies for the number of segments in which a firm operates, as reported by the firm. Robust standard errors are clustered by firm. Table 3 reports the results.

- Please insert Table 3 here -

The results of Regression (1) largely corroborate the results of Schlingemann, Stulz, and Walkling (2002). The table provides weak support for the conjecture that CEOs are more likely to divest assets from poorly performing segments, although the two cash flow coefficients are not statistically significant. The results further indicate that CEOs are more likely to divest assets from segments with lower capital expenditures that operate in industries with higher capital expenditures, possibly to economize on cash flows. Segments with greater cross subsidization are also more likely to be divested. The probability of divestment is higher for relatively larger segments (as proxied by segment relative to firm sales). Our results further indicate that CEOs' choice of which assets to divest is not influenced by a

\footnotetext{
${ }^{8}$ Note that the focus argument applies to fully divested segments, as the proportion of core segments in this subsample of fully divested segments drops to $9.5 \%$.

${ }^{9}$ We control in our tests for core versus non-core segments based on segment size and two-digit SIC classification. In unreported robustness analyses, we investigate several alternative proxies to distinguish segments that may have a special status within a company (e.g., core segments based on two-digit SIC only, core segments based on threedigit SIC only, and the largest segment based on sales). These alternative proxies do not affect our results for the familiarity effect.
} 
segment's imputed $q$ or whether a segment is core or its sales account for less than $10 \%$ of a firm's consolidated sales.

To investigate whether familiarity influences CEOs' divestment decisions, Regression (2) includes the direct-experience dummy. We find, consistent with the comparative information hypothesis, that CEOs are less likely to divest assets from segments in which they have worked, which effect is economically significant. An odds ratio of 0.61 indicates that asset divestment occurs only $61 \%$ as often among direct-experience as among non-familiar segments. Including the direct-experience dummy significantly increases the regression's explanatory power. ${ }^{10,11}$

Regressions (3) and (4) report robustness checks related to the literature on the impact of CEO background on corporate decisions, in which a distinction is made between generalist and specialist CEOs (e.g., Custódio, Ferreira, and Matos (2013)). In our study, the familiarity effect is observed in firms run by both generalist (as part of their broad background) and specialist (in the to-be-divested segment) CEOs. The effect can also, however, be absent in both groups, as when generalist CEOs' experience is not per se specifically related to the segment or specialist CEOs' skills and experience are not related to the divesting segment. The overlap between our definitions and the literature's specialist-generalist distinction is thus not predetermined and remains an empirical question.

To test whether our documented familiarity effect is more (or less) apparent in firms with generalist or specialist CEOs, Regressions (3) and (4) interact our direct-experience dummy with a specialist and generalist dummy, respectively. We use two definitions to distinguish specialists and generalists. First, we define specialist CEOs as having direct work experience in one (and not more than one) segment within a firm year. By this definition, $68 \%$ of segments are managed by specialist CEOs. Second, we define generalist CEOs as being relatively knowledgeable, through either direct or industry work experience, about all segments within a firm year. We use both levels of experience because we need variation in familiarity within a firm year. Under this condition, $27 \%$ of segments are managed by generalist CEOs. That the regression results show the interaction terms in both regressions to not be

\footnotetext{
${ }^{10} \mathrm{We}$ also analyze whether the number of years of work experience in these segments reinforces the documented familiarity effect and find that it does not. This result (not reported) implies that having worked for a segment drives the familiarity effect and is more important than the duration of experience in the segment.

${ }^{11} \mathrm{We}$ also investigate the related question of whether the presence of familiar segments affects the proportion of assets firms divest. We find in regression models that explain total transaction value over assets at a firm-year level that none of our firm-level familiarity measures has a significant effect. That is, familiarity does not affect the corporate strategy to divest; it only affects the decision on which segment to divest. These results are available upon request from the authors.
} 
significantly different from zero suggests that the familiarity effect is similar between firms headed by specialist and generalist CEOs. Applying the Delta method (as described in Ai and Norton (2003)) to the interaction term yields the same conclusion.

A final set of robustness tests (unreported) provides a detailed analysis of the role of core segments in the familiarity effect. The statistics in Table 2 revealed that familiar segments are significantly larger and more often core segments. If boards promote to the CEO position primarily managers with work experience in core segments, the negative coefficient of the direct experience dummy in our reported regressions might reflect firms' decision to focus on their core businesses, which would suggest that the documented familiarity effect is a mechanical relation. We address this issue in two ways. First, we add to our basic regression an interaction term between the direct-experience segment and core segment dummies, as reported in Regression (2) of Table 3. We find the coefficient of the directexperience segment dummy to remain significantly negative and the interaction term to be significantly positive, with a $p$-value of 0.032 (the average interaction effect is also significant at the five-percent level when the Delta method is applied), which is contrary to the prediction of a mechanical relation. Were the mechanical relation explanation to hold, we would expect the familiarity effect to prevail in core segments, but the regression results suggest that the effect is present mainly in non-core, and not present in core, segments.

As a second test of the mechanical relation explanation, we construct two samples of firm years, (1) firm years in which managers promoted to CEO are from the core segments (i.e., firm years in which the direct-experience segments are also core segments), and (2) firm years in which managers promoted to CEO are from non-core segments (i.e., firm years in which the direct-experience segments are non-core segments). For the mechanical relation explanation to hold, the familiarity effect should prevail in the first, and not in the second, sample. Although we find a negative direct-experience coefficient in both subsamples, the coefficient is only significant in the subsample of firm years in which managers promoted to CEO were from non-core segments (with a $p$-value below one percent). Overall, these extra tests do not support a significant mechanical relation between familiarity and the likelihood of a segment being divested.

\subsection{Testing the political power hypothesis}

We document in the previous section, for a cross-section of divesting multi-segment firms, that CEOs faced with a divestment decision are inclined to hold onto familiar segments, which evidence supports the comparative information hypothesis. The possession of superior knowledge of familiar segments that drives CEOs' preference for divesting non-familiar segments must be complemented, however, by a 
sufficient accumulation of political capital to support implementation of the preferred choice of which segment(s) to divest.

We test this political power hypothesis by splitting the sample into CEOs with tenure of up to two years and CEOs with tenure of three or more years. The two-year cutoff follows Xuan (2009), who argues that newly hired CEOs are particularly susceptible to political complications and especially likely to increase investment in non-familiar segments to promote goodwill towards their managers. Changing the threshold to three years does not change our conclusions. Regressions (1) and (2) in Table 4 show the results for newly hired, Regression (3) for longer-tenured, CEOs.

\section{- Please insert Table 4 here -}

That Regression (1) shows no significant direct-experience coefficient for newly hired CEOs suggests that, consistent with the political power hypothesis, CEOs new to the job have not accumulated sufficient political capital to act on their preferences. We further test the political power hypothesis for newly hired CEOs by distinguishing between those who held the corporate executive title of chief operating officer (COO) before being promoted to CEO and those who did not. Of the sample of new CEOs, $71 \%$ held the title of COO before being appointed CEO. According to Xuan (2009), new CEOs who previously held the title of COO have less need to "bridge-build" with managers of non-familiar segments because the former title accords them status as successor and thereby authority in the firm. Regression (2) shows an interaction term added between the direct-experience dummy and COO title dummy to be significantly negative (the average interaction effect is also significant at the five-percent level when the Delta method is applied). Moreover, the direct-experience dummy is now positively associated with the likelihood of divestment. These results suggest that the least powerful new CEOs are inclined to seek the goodwill of managers of non-familiar segments by not divesting assets from their segments, which reverse familiarity effect is not exhibited by new CEOs with more authority (the $p$-value of the sum of the direct experience coefficient and interaction coefficient is 0.323 ).

For the subsample of longer-tenured CEOs, the direct-experience coefficient is significantly negative (Regression (3)). The odds ratio of 0.486 suggests that $51.4 \%$ fewer divestments are experienced by direct-experience than by non-familiar segments. This is in line with our conjecture that longer-tenured CEOs have accumulated sufficient political power to implement their preference for divesting nonfamiliar segments.

Our evidence overall supports the political power hypothesis. New CEOs with the least authority favor non-familiar, more established CEOs who have accumulated sufficient political capital, familiar, segments in their divestment decisions. 


\subsection{Additional tests of the comparative information hypothesis}

The reduced likelihood of established CEOs divesting familiar segments is consistent with the comparative information hypothesis. We further test this hypothesis by investigating whether the familiarity effect is more pronounced in segments in which CEOs' comparative information advantage is greater. We first add another dimension of familiarity with segments based mainly on industry experience. We next investigate instances in which a deeper understanding of a segment's (and its industry's) products, processes, and technology is required.

The comparative information advantage may depend on whether segments operate in the same industry as a CEO's direct-experience segment. If so, the knowledge and industry background the CEO shares with segment managers stimulates information sharing between the two parties. We therefore maintain that CEOs are more knowledgeable about related (also referred to as industry-experience) than unrelated segments. They nevertheless have less firsthand knowledge about industry-experience than about their direct-experience segments. The intuition behind this difference is that CEOs possess more abundant specific knowledge of segments in which they have worked, and enjoy stronger connections, and a concomitant greater level of trust, with those with whom they worked in their direct-experience segments. We therefore expect CEOs to divest assets from segments with which they are least familiar.

\section{- Please insert Table 5 here -}

Regression (1) of Table 5 adds to our logit regression a dummy variable for industry experience that explains a segment's likelihood of being divested by established CEOs. The industry-experience coefficient is negative and significant at the ten-percent level. Consistent with our prior, its effect is smaller and less significant than the direct-experience effect. We conclude from these results that CEOs' comparative information advantage diminishes with distance from firsthand knowledge about, which increases their willingness to divest, a given segment.

Turning to segments that operate in R\&D intensive industries in which CEOs' comparative information advantage with respect to familiar segments should be greater, we find assessments of $R \& D$ investments to typically be much more information-sensitive compared to investments in low $R \& D$ activities. One reason is that the outcomes of investment in R\&D are highly uncertain and difficult to accurately assess at the investment stage. According to Miao and Sandford's (2013) model, this results in a comparative advantage that leads CEOs to retain familiar segments. Another reason is that R\&D decisions are based on soft information that is difficult to quantify and transmit in an impersonal way (Petersen (2004)). In such a setting, CEOs must rely on information provided by segment managers, who consequently have more leeway to overstate their segments' needs and prospects in the hope of receiving a greater budget allocation. A natural response of CEOs is to more greatly discount these segments' budget requests (Bernardo, Cai, and Luo (2001)), asset divestments being an extreme form of discount. 
We argue that CEOs' direct work experience in R\&D intensive segments can overcome this asymmetric information problem by affording a deeper understanding of the products, processes, and technologies of these segments and their competitors, which should diminish the incentives for managers to misrepresent their segments' needs and prospects. Moreover, more frequent personal encounters, and a greater degree of mutual trust, between CEOs and direct-experience segment managers should enhance the formers' access to soft and more accurate information. CEOs do not possess the same information benefits in the case of non-familiar segments. For the comparative information advantage hypothesis to hold, the familiarity effect should be particularly pronounced for segments that operate in $R \& D$ intensive industries.

To test this expectation, Regression (2) of Table 5 adds to the logit regression an interaction term between the direct-experience dummy and a dummy for segments that operate in $R \& D$ intensive industries (i.e., single-segment industry R\&D expenditures to total assets above the sample median) that explains the likelihood of divestment by longer-tenured CEOs. Our finding of a negative interaction coefficient significant at the five-percent level (the $p$-value of the average interaction effect when the Delta method is applied is 0.057) suggests that the likelihood of established CEOs divesting segments that operate in R\&D intensive industries is significantly lower for direct-experience than for non-familiar segments. ${ }^{12}$ This difference is not significant for segments that operate in low R\&D intensive industries.

\section{Alternative explanations}

We examine here three competing explanations for why CEOs choose to keep business segments in which they have previously worked, one based on CEO selection by boards, one on internal promotion considerations, and the other on CEO entrenchment.

\subsection{Board CEO selection}

Considerations in the CEO selection process may be the underlying explanation for the familiarity effect, inasmuch as boards of directors take into account candidates' prior work experience in the selection process for a new CEO. If, for example, a board chooses a CEO with the aim of focusing on and growing, as part of long-term firm strategy, a business segment with which the candidate is familiar, segments with which the new CEO is not familiar will be strategically less important. In such instances, CEOs will be less likely to divest assets from familiar segments. Huang (2010), investigating divestments of complete segments in relation to an industry-based measure for the match between CEO expertise and retained

\footnotetext{
${ }^{12}$ This result also holds when the industry-experience dummy is added to the regression.
} 
assets, finds evidence that the appointment of CEOs improves firm performance in cases of a match between CEO expertise and firm assets.

Our finding that the preference to divest from non-familiar segments is not exhibited during the first two years of a CEO's tenure argues against the board CEO selection explanation. Weisbach (1995) argues that newly appointed CEOs are least likely to divest assets congruent with their skill sets. Moreover, CEOs with two or three years of tenure have typically acquired adequate knowledge from different sources and gained sufficient political leverage to support deviations from their original mandate (Hambrick and Fukutomi (1991)). The familiarity effect, if it is explained by board CEO selection, should be pronounced early in a CEO's tenure, which is not what we find.

We nevertheless further test the selection explanation using a two-step procedure to distinguish between the board selection decision and CEO divestment decision. We first estimate a model to predict which segment is likely to be divested. We use for this purpose our standard model as presented in Regression (1) of Table 3, taking the full sample of 608 firm years, rather than the subsample of firm years with variation in familiarity, to minimize the likelihood that any form of familiarity would affect the determinants of segment divestment (see Section 2.1 for our sample selection procedure). Regression (2), because it incorporates only segments in firm years with CEOs who succeed to that position one or two years prior to divestment, provides a stronger specification for testing the selection explanation, and Regression (3) an even stronger specification in using the subset of divesting firm years with externally hired CEOs with tenure up to two years. ${ }^{13}$ The skills of the latter group of CEOs should relate to the remaining assets and be less correlated with recently divested assets.

In the second step, we use the first-step coefficients to predict the probability of a segment's assets being divested using information from one year prior to CEO appointment. If CEOs were hired to grow their direct-experience segment, the predicted probability of a segment being divested should be the lowest (highest) for the direct-experience (non-familiar) segments. Because the year of CEO appointment can occur prior to 1996, and our estimation period is from 1996 to 2004, we do not control in the firststep regression for the year in which divestment takes place. Our sample contains 70 CEO-firm combinations and 236 segment years. ${ }^{14}$ Table 6 presents the results.

\footnotetext{
${ }^{13}$ Our results also hold when we estimate the regression based on a subset of divesting firm years with all externally hired CEOs (i.e., both newly-hired and longer-tenured external CEOs) (results are unreported).

${ }^{14}$ The sample of firm years with variation in familiarity contains 134 CEO-firm combinations. We remove 64 combinations for the following reasons: for $31 \mathrm{CEO}$-firms no financial data is available or we observe a change in segment reporting (we lose firm years when we miss information for even one segment within a firm year); for 13 CEO-firms, the firms report one segment when the CEO was appointed; for five CEO-firms, we cannot download
} 
- Please insert Table 6 here -

Panel A reports the coefficients for the three regression models that estimate the predicted probability of a segment being divested, Panel B the statistics of the predicted probability per level of familiarity in the year prior to CEO appointment based on all three regression models in Panel A. With an average predicted probability of $41.5 \%$ and median of $40.0 \%$ (using Regression (1) from Panel A), our results suggest, contrary to the hypothesis, that boards do not appoint CEOs whose direct-experience segments have the lowest predicted probability of being divested. Moreover, the average and median predicted probabilities for direct-experience segments are significantly higher than those for non-familiar segments ( $p$-value equals 0.003 and 0.001 , respectively). Our results are robust to using different regression specifications (as documented in Panel A); the average or median predicted probability of being divested is not significantly larger for direct-experience than for non-familiar segments with any of these specifications. We find a similar predicted probability of being divested for industry-experience relative to non-familiar segments.

Overall, our evidence does not support the CEO selection explanation for the familiarity effect, but suggests instead that boards select CEOs to restructure their direct-experience segments. Our earlier finding that newly hired CEOs with the least political power tend to divest direct-experience segments is consistent with this prediction. For the selection story to hold, however, the familiarity effect should exist for new CEOs with and without authority (as discussed in Section 3.2).

\subsection{Internal promotion considerations}

Another selection argument offered as an alternative explanation for the documented familiarity effect is that managers of poorly performing segments are unlikely to be promoted to the CEO position. Put differently, CEOs are more likely to advance from the ranks of well performing segments, which are the least likely to be divested. Our empirical evidence does not support this alternate explanation. For this explanation to hold, we should observe the familiarity effect mainly at the beginning of a CEO's tenure, which we do not. Another implication is that the direct-experience segments of firms managed by new CEOs should perform better than non-familiar segments. But a comparison (not tabulated) of the segments' and industry-adjusted cash flows for the subsample of newly hired CEOs does not show a significant difference in performance ( $p$-values of the difference equal 0.599 and 0.610 for segment and

the information from Compustat because the CEO was appointed prior to 1979 or because no Compustat coverage exists in the year prior to appointment; for two CEO-firms we lose variation in familiarity between segments; and for 13 cases the CEO had been appointed in the year of the divestment (if these observations were included, the estimation of the model and predicted probability would be based on the same data). 
industry-adjusted segment cash flows, respectively). That we document in the previous section a lower rather than higher predicted probability of a segment being divested is yet further evidence counter to the selection explanation.

\subsection{Managerial entrenchment}

CEOs might favor familiar segments based on agency theory. One way to maximize their utility is for CEOs to facilitate their entrenchment, as by investing in assets that are complementary to their skills and thereby making themselves more valuable to shareholders and more costly to replace (Shleifer and Vishny (1989)). CEOs can achieve the same end by divesting assets from non-familiar segments and increasing the share of familiar assets.

Being the agents who realize the greatest marginal benefits from actions to entrench themselves, our finding that newly hired CEOs do not exhibit a significant familiarity effect is evidence against the entrenchment explanation. In untabulated analyses, we perform two additional tests in which we consider entrenchment as related to external and internal governance. ${ }^{15}$ We use as an external governance measure the entrenchment index of Bebchuk, Cohen, and Ferrell (2009), which contains six provisions that isolate executives from hostile acquisitions and from shareholders' ability to impose their will on them. If entrenchment explains the familiarity effect, we expect more entrenched CEOs to manifest a stronger familiarity effect. Although one could argue that already entrenched CEOs need not divest non-familiar segments to facilitate their entrenchment, we expect entrenched managers, having to choose which assets to divest, not to take actions that could undo their entrenchment. We test this hypothesis by including in Regressions (1) and (3) of Table 4 an interaction term with the direct-experience dummy and a dummy for an above sample median entrenchment index (i.e., equal to three or higher). That we find neither newly hired nor established CEOs with a high entrenchment index to exhibit a stronger familiarity bias argues against the entrenchment explanation.

We use for our second test of the entrenchment explanation a measure of internal corporate governance. We expect good corporate governance to induce CEOs to make value-maximizing decisions for the firm rather than for themselves. CEOs of firms with more independent directors have less power over the board, hence, less discretion over their decisions (e.g., Ryan and Wiggins III (2004), Moeller (2005), and Paul (2007)). If the familiarity effect is occasioned by the desire to become entrenched, CEOs in well governed firms would not exhibit this bias. Again, we find no supporting evidence for the entrenchment explanation, as an interacting term with the direct-experience dummy and dummy for above median percentage of independent directors is not significant in the sample of either newly hired or

\footnotetext{
${ }^{15}$ The results are available upon request.
} 
longer-tenured CEOs. Using other governance measures, such as CEO ownership or the Gompers, Ishii, and Metrick (2003) governance index, yields the same conclusion.

\section{The value-relevance of familiarity}

Our results thus far suggest that CEOs' comparative information advantage leads to a preference to divest from non-familiar segments, but that insufficient political power can constrain them to act on their preference. We find the familiarity effect to be significant for longer-tenured CEOs and to pertain to R\&D intensive industries. This section investigates, by means of an event study, how the stock market perceives the familiarity effect.

How the market response to divestment announcements of familiar assets differs from that of non-familiar assets is an empirical question. On the one hand, divesting familiar assets, relative to nonfamiliar assets, can generate lower abnormal returns. Because other managers have less knowledge of how best to manage and improve the performance of familiar assets, there is smaller potential gain for higher-valued users, resulting in a lower premium for the assets. On the other hand, the returns from divesting familiar assets may be higher than returns from divesting non-familiar assets, as CEOs can use their superior information to pick winners (Stein (1997)) by divesting underperforming assets from familiar segments or exploiting an overvaluation of their assets. Additionally, CEOs who divest familiar assets have a comparative advantage in locating and bargaining with potential buyers. Previous studies provide empirical evidence consistent with these arguments by showing that acquiring firms in close geographic proximity (Uysal, Kedia, and Panchapagesan (2008)) or that operate in industries in which CEOs have work experience (Custódio and Metzger (2012)) generates higher abnormal returns.

Both the predicted positive and negative impact of familiarity on announcement returns are based on CEOs' comparative information advantage. Although CEOs' knowledge of familiar segments is more unique in $R \& D$ intensive industries, we expect the market response to asset divestments in these industries to be negatively influenced by $R \& D$ intensity of assets. The uniqueness of $R \& D$ intensive assets gives investors an information disadvantage in getting a reliable estimate of the value of these assets (Aboody and Lev (2000)). Moreover, not only investors, but also potential buyers of the target's assets experience more uncertainty in their assessment, which would rationally lead to a discount on the price they are willing to pay. ${ }^{16}$

Because established CEOs have the political power to more freely act according to their preference to divest from non-familiar segments, they may also be more likely to effectively use their

\footnotetext{
${ }^{16}$ In line with this argument, Cooney, Moeller, and Stegemoller (2009) show that acquirers account for valuation uncertainty of private targets by paying a lower price.
} 
comparative information advantage in their divestment decisions. We therefore distinguish in our analysis between newly-hired and longer-tenured CEOs.

Our sample includes 500 divested business units. Of those announcements, we have 438 observations with available return data on a unique divestment date. ${ }^{17}$ To avoid the possibility that outliers drive our results, we winsorize CAR at the one- and 99-percentiles. Table 7, Panel A provides the abnormal return statistics for the sample of 438 observations as well as for a sample of 208 observations for which we have complete information. We end up with 208 observations because we lose 213 observations due to missing transaction values and another 17 observations due to missing values for industry-adjusted capital expenditures and CEO equity ownership. Panel A further reports statistics for the subsamples of divestments of direct-experience, industry-experience, and non-familiar segments and for the subsamples of longer-tenured and newly hired CEOs.

\section{- Please insert Table 7 here -}

Our results show an average positive market response to divestment announcements that varies across types of divestment. In the sample with fully available information, we find direct-experience divestments to generate, on average, $1.27 \%$ abnormal returns, which is the strongest market response across the various types of divestment. Divestments of non-familiar segments generate an insignificant average of $0.34 \%$. The difference, however, is not significant ( $p$-value equals 0.157 ). Splitting the sample into divestments announced by newly hired and longer-tenured CEOs exacerbates the difference; a positive average abnormal return of $1.62 \%$ for announced divestments of direct-experience segments by longer-tenured CEOs compares to a positive average abnormal return of $0.18 \%$ for announced divestments of non-familiar segments by such CEOs. ${ }^{18}$

Panel B of Table 7 presents estimates of ordinary least squares regressions in which we regress the three-day abnormal returns on the familiarity dummies and a number of control variables. We follow Bates (2005) for the specification of the control variables, which include relative transaction size, firm Tobin's $q$, industry-adjusted capital expenditures, industry-adjusted leverage and cash, and percentage of stock owned by the CEO. We use the 208 observations with available information, it being crucial to know relative transaction size (the variable responsible for the greatest drop in observations) to account

\footnotetext{
${ }^{17}$ By unique divestment date, we refer to 13 cases in which SDC reports two or three separate divestment announcements occurring on the same date in the same segment (but for separate business units). In such instances, we aggregate the information into one observation.

${ }^{18}$ With a $p$-value equal to 0.081 , this difference is statistically significant. We do not find significance at the tenpercent level for the full sample of divestment announcements by longer-tenured CEOs, which includes observations for which transaction values are unavailable.
} 
for the economic significance of divestments. The average (median) transaction value of divestments amounts to $5.5 \%(1.1 \%)$ of the book value of the firms' total assets; the 25- and 75-percentiles are, respectively, $0.3 \%$ and $5.5 \%$.

That Regression (1) yields a positive and significant direct-experience coefficient suggests that divestments of direct-experience segments generate $1.23 \%$ higher abnormal returns than divestments of other segments. Divestments that increase a firm's focus being positively related to firm performance (Berger and Ofek (1995)), we add to Regression (2) the variables excess value and a core dummy. We find a significant coefficient for neither the core-segment dummy nor the excess-value effect on abnormal returns. But although the coefficient of the direct-experience effect is unaffected, the $p$-value drops to 0.128. This drop in significance being driven mainly by the core-segment dummy, we run an additional (unreported) robustness check in which we add to Regression (2) an interaction term between the directexperience and core-segment dummy. We find the interaction term to not be significant, and the significance of the direct-experience coefficient to increase to the ten-percent level, which suggests that the positive market response can be attributed to the divestment of non-core direct-experience segments.

Because we find the familiarity effect to be exhibited by more powerful CEOs, in Regression (3) we split the direct-experience dummy into direct-experience dummies for longer-tenured and newly hired CEOs. With a $p$-value equal to 0.115 , we find weak evidence that shareholders reward direct-experience sales by longer-tenured CEOs with $1.6 \%$ abnormal returns. Again, in an unreported robustness check, we find the market response to become significant at the ten-percent level for non-core direct-experience segments. Although longer-tenured CEOs tend to be reluctant to sell assets from direct-experience segments, their superior information helps them generate higher abnormal returns if they shall decide to divest. The direct-experience dummy is not significant for newly hired CEOs. Introducing industry experience in Regression (4) yields no significant effect.

In Regression (5), we interact direct experience for longer-tenured CEOs with R\&D intensity. These results should be interpreted with care because the below-median sample of R\&D activities has 21 observations and the above-median sample 18 observations. We find the positive announcement effect to be driven by the low R\&D subsample, and the magnitude of the effect to be as large as $2.4 \%$. Overall, these results imply that the valuation effect underpins the value-relevance of the familiarity effect in cases in which CEOs have sufficient direct work experience and political power to make divestment decisions according to their preferences and thereby maximize their comparative information advantage. Financial market reactions are most favorable, however, when investors have the least difficulty assessing the value of divestments. 


\section{Conclusion}

Our paper examines the impact of CEOs' career paths on corporate decisions. We examine how familiarity arising from work experience in a segment or its industry influences CEOs' divestment decisions. We empirically show CEOs to be less likely to divest assets from familiar than from nonfamiliar segments.

Further analyses demonstrate the familiarity effect to be driven by a trade-off between two forces, a comparative information advantage and political power. CEOs have an information advantage with respect to familiar segments because of their deeper understanding of the segments' business. Consistent with our prediction, we find a stronger effect for direct than for industry experience and the familiarity effect to be more pronounced in high R\&D intensive industries. CEOs also need to possess sufficient political power to act according to their preferences. We find, in line with this conjecture, the familiarity effect to be significant in the sample of longer-tenured, but not newly hired, CEOs. We finally investigate the value effects of familiarity. Divestments of direct-experience segments exhibit a $1.2 \%$ higher abnormal return. Returns are especially high for longer-tenured CEOs' divestments of direct-experience segments in low R\&D intensity firms. Our findings contribute to the investment and internal capital markets literature by emphasizing the relevance of CEO background and internal politics to the determination of firm strategy. 


\section{References}

Aboody, D., and B. Lev. 2000. Information asymmetry, R\&D, and insider gains. Journal of Finance 55: 2747-2766.

Ahn, S., and D. J. Denis. 2004. Internal capital markets and investment policy: Evidence from corporate spinoffs. Journal of Financial Economics 71: 489-516.

Ai, C., and E. C. Norton. 2003. Interaction terms in logit and probit models. Economics Letters 80: 123129.

Bates, T. W. 2005. Asset sales, investment opportunities, and the use of proceeds. Journal of Finance 60: 105-135.

Bebchuk, L. A., A. Cohen, and A. Ferrell. 2009. What matters in corporate governance? Review of Financial Studies 22: 783-827.

Berger, A. N., Q. Dai, S. Ongena, and D. C. Smith. 2003, To what extent will the banking industry be globalized? Evidence of bank nationality and reach in 20 European nations. Journal of Banking \& Finance 27: 383-415.

Berger, P. G., and R. N. Hann. 2003. The impact of SFAS no. 131 on information and monitoring. Journal of Accounting Research 41: 163-223.

Berger, P. G., and R. N. Hann. 2007. Segment profitability and the proprietary and agency costs of disclosure. The Accounting Review 82: 869-906.

Berger, P. G., and E. Ofek. 1995. Diversification's effect on firm value. Journal of Financial Economics 37: 39-65.

Bernardo, A. E., H. Cai, and J. Luo. 2001. Capital budgeting and compensation with asymmetric information and moral hazard. Journal of Financial Economics 61: 311-344.

Bertrand, M., and A. Schoar. 2003. Managing with style: The effect of managers on firm policies. Quarterly Journal of Economics 143: 1169-1208.

Chang, Y. Y., S. Dasgupta, and G. Hillary. 2010. CEO ability, pay, and firm performance. Management Science 56: 1633-1652.

Cooney, J. W, T. Moeller, and M. Stegemoller. 2009. The underpricing of private targets. Journal of Financial Economics 93: 51-66.

Custódio, C., M.A. Ferreira, and P. Matos. 2013. Generalists versus specialists: Lifetime work experience and chief executive officer pay. Journal of Financial Economics 108: 471-492.

Custódio, C., and D. Metzger. 2012. How do CEOs matter? Industry expertise on acquisition returns. Working paper, Stockholm School of Economics.

Dittmar, A., and A. Shivdasani. 2003. Divestitures and divisional investment policies. Journal of Finance 58: $2711-2743$. 
Duchin, R., and D. Sosyura. 2013. Divisional managers and internal capital markets. Journal of Finance 68: $387-429$.

French, K. R., and J. M. Poterba. 1991. Investor diversification and international equity markets. American Economic Review 81: 222-226.

Gaspar, J., and M. Massa. 2011. The role of commonality between CEO and divisional managers in internal capital markets. Journal of Financial and Quantitative Analysis 46: 841-869.

Gompers, P. A., J. L. Ishii, and A. Metrick. 2003. Corporate governance and equity prices. Quarterly Journal of Economics 118:107-155.

Hambrick, D. C., and G. D. S. Fukutomi. 1991. The seasons of a CEO's tenure. The Academy of Management Review 16: 719-742.

Harris, M., and A. Raviv. 1996. The capital budgeting process: Incentives and information. Journal of Finance 51: 1139-1174.

Harris, M., and A. Raviv. 1998. Capital budgeting and delegation. Journal of Financial Economics 50: 259-289.

Huang, S. 2010. CEO characteristics, corporate decisions, and firm value: Evidence from corporate refocusing. Working paper, Singapore Management University.

Huberman, G. 2001. Familiarity breeds investments. Review of Financial Studies 14: 659-680.

Jain, P. C. 1985. The effect of voluntary sell-off announcements on shareholder wealth. Journal of Finance 40: 209-224.

Jensen, M. C. 2003. Paying people to lie: The truth about the budgeting process. European Financial Management 9: 379-406.

John, K., and E. Ofek. 1995. Asset sales and increase in focus. Journal of Financial Economics 37: 105126.

Kahle, K. M., and Walkling, R. A. 1996. The impact of industry classifications on financial research. Journal of Financial and Quantitative Analysis 31: 309-335.

Lamont, O. 1997. Cash flow and investment: Evidence from internal capital markets. Journal of Finance 52: 83-109.

Landier, A., V. B. Nair, and J. Wulf. 2009. Tradeoffs in staying close: Corporate decision-making and geographic dispersion. Review of Financial Studies 22: 1119-1148.

Lang, L., A. Poulsen, and R. M. Stulz. 1995. Asset sales, firm performance, and the agency costs of managerial discretion. Journal of Financial Economics 37: 3-37.

Li, K. 2004. Confidence in the familiar: An international perspective. Journal of Financial and Quantitative Analysis 39: 47-68. 
MacKinlay, A. G. 1997. Event studies in economics and finance. Journal of Economic Literature 35: 1339.

Maksimovic, V., and G. Philips. 2007. Conglomerate firms and internal capital markets, in EspenEckbo, B. (eds.), Handbook of Corporate Finance: Empirical Corporate Finance, Vol. 1. Elsevier: North Holland.

Miao, C.-H., and J. Sandford. 2013. Information-based favoritism. Working paper, University of South Carolina and University of Kentucky.

Malmendier, U., and G. Tate. 2005. CEO overconfidence and corporate investment. Journal of Finance 60: 2661-2700.

Malmendier, U., and G. Tate. 2008. Who makes acquisitions? CEO overconfidence and the market's reaction. Journal of Financial Economics 89: 20-43.

McNeil, C. R., and W. T. Moore. 2005. Dismantling internal capital markets via spinoff: Effects on capital allocation efficiency and firm valuation. Journal of Corporate Finance 11: 253-275.

Milgrom, P., and J. Roberts. 1988. An economic approach to influence activities in organizations. American Journal of Sociology 94: 154-179.

Moeller, T. 2005. Let's make a deal! How shareholder control impacts merger payoffs. Journal of Financial Economics 76: 167-190.

Murphy, K. J., and J. Zabojnik. 2004. CEO pay and appointments: A market-based explanation for recent trends. American Economic Review Papers and Proceedings 94: 192-196.

Parwada, J. T. 2008. The genesis of the home bias? The location and portfolio choices of investment company start-ups. Journal of Financial and Quantitative Analysis 43: 245-266.

Paul, D. 2007. Board composition and corrective action: Evidence from corporate responses to bad acquisition bids. Journal of Financial and Quantitative Analysis 42: 759-784.

Petersen, M.A. 2004. Information: Hard and soft. Working paper, Kellogg School of Management, Northwestern University and NBER.

Rajan, R., H. Servaes, and L. Zingales. 2000. The cost of diversity: The diversification discount and inefficient investment. The Journal of Finance 55: 35-80.

Ryan Jr., H. E., and R. A. Wiggins III. 2004. Who is in the pocket? Director compensation, board independence, and barriers to effective monitoring. Journal of Financial Economics 73: 497-524.

Sarkissian, S., and M. J. Schill. 2004. The overseas listing decision: New evidence of proximity preference. Review of Financial Studies 17: 769-809.

Schlingemann, F. P., R. M. Stulz, and R. A. Walkling. 2002. Divestitures and the liquidity of the market for corporate assets. Journal of Financial Economics 64: 117-144. 
Shleifer, A., and R. W. Vishny. 1989. Management entrenchment: The case of manager-specific investments. Journal of Financial Economics 25: 123-139.

Stein, J. C. 1997. Internal capital markets and the competition for corporate resources. Journal of Finance 52: 111-133.

Stein, J. C. 2003. Agency, information and corporate investment, in Constantinides, G., M. Harris, and R. M. Stulz (ed.), Handbook of the Economics of Finance. Elsevier: North Holland.

Uysal, V. B., S. Kedia, and V. Panchapagesan. 2008. Geography and acquirer returns. Journal of Financial Intermediation 17: 256-275.

Weisbach, M. S. 1995. CEO turnover and the firm's investment decisions. Journal of Financial Economics 37: 159-188.

Wulf, J. 2009. Influence and inefficiency in the internal capital market. Journal of Economic Behavior \& Organization 72: 305-321.

Xuan, Y. 2009. Empire-building or bridge-building? Evidence from new CEOs' internal capital allocation decisions. Review of Financial Studies 22: 4919-4948. 


\section{Table 1: Firm and CEO summary statistics}

The table shows the means, standard deviations, minimum and maximum values, and number of observations of firm, divestment, and CEO variables. Leverage is debt divided by total assets. Net capital expenditures are gross capital expenditures minus depreciation and amortization. We define cash flows as operating profit plus depreciation and amortization. Tobin's $q$ is the ratio of the market-to-book value of assets as calculated in Malmendier and Tate $(2005,2008)$. We calculate the excess value measure as in Berger and Ofek (1995), diversity in $q$ as in Rajan, Servaes, and Zingales (2000), and the entrenchment index as in Bebchuk, Cohen, and Ferrell (2009). We define independent directors as the percentage of independent directors relative to all directors. Fully divested segments are segments that are completely divested and cease to be reported by firms post divestment. The aggregate transaction value is the sum of the transaction values of all divested business units within a firm year (we require firms to report the transaction value of at least one divestment within a firm year). Direct-experience segments are segments in which a CEO worked prior to appointment as CEO. Industry-experience segments are segments that operate in the same two-digit SIC industry as the direct-experience segments.

\begin{tabular}{|c|c|c|c|c|c|}
\hline & Mean & SD. & Minimum & Maximum & $\mathrm{N}$ \\
\hline \multicolumn{6}{|l|}{ Panel A. Firm summary statistics } \\
\hline Sales $_{t-1}(\$ M)$ & 10,641 & 18,508 & 141 & 153,627 & 266 \\
\hline Assets $_{t-1}(\$ M)$ & 13,977 & 33,274 & 175 & 279,097 & 266 \\
\hline Leverage & 0.646 & 0.143 & 0.251 & 1.000 & 266 \\
\hline Capx $_{t-1} /$ sales $_{t-2}$ & 0.013 & 0.057 & -0.228 & 0.457 & 266 \\
\hline Cash flow $_{t-1} /$ sales $_{t-2}$ & 0.193 & 0.099 & -0.051 & 0.859 & 266 \\
\hline Tobin's $q$ & 1.877 & 1.059 & 0.241 & 7.302 & 266 \\
\hline Number of business segments & 3.470 & 1.172 & 2.000 & 7.000 & 266 \\
\hline Diversity in $q$ & 0.118 & 0.116 & 0.000 & 0.492 & 258 \\
\hline Excess value & 0.105 & 0.486 & -1.386 & 1.386 & 244 \\
\hline Entrenchment index & 2.417 & 1.410 & 0 & 5 & 266 \\
\hline Independent directors & 0.671 & 0.156 & 0.222 & 0.917 & 255 \\
\hline \multicolumn{6}{|l|}{ Panel B. Divestment statistics } \\
\hline Number of segments with a divestment & 1.323 & 0.577 & 1 & 4 & 266 \\
\hline Dummy for firm years with a fully divested segment & 0.154 & 0.362 & 0 & 1 & 266 \\
\hline Number of segments with a fully divested segment & 0.158 & 0.376 & 0 & 2 & 266 \\
\hline Aggregate transaction value of all divested business units $(\$ M)$ & 534 & 1,037 & 1 & 7,500 & 177 \\
\hline Aggregate transaction value of all divested business units/assets $t-1$ & 0.108 & 0.205 & 0 & 1.402 & 177 \\
\hline \multicolumn{6}{|l|}{ Panel C. CEO summary statistics } \\
\hline Number of direct experience segments & 1.331 & 0.605 & 1 & 4 & 266 \\
\hline Dummy for firm years with industry-experience segments & 0.598 & 0.491 & 0 & 1 & 266 \\
\hline Number of industry-experience segments & 0.880 & 0.928 & 0 & 5 & 266 \\
\hline Years employed as CEO & 5.523 & 5.463 & 0 & 30 & 266 \\
\hline Years worked for firm & 23.802 & 10.117 & 2 & 47 & 258 \\
\hline Number of titles (CEO, president, chairman) & 2.158 & 0.489 & 1 & 3 & 247 \\
\hline CEO age & 56.342 & 6.121 & 40 & 74 & 266 \\
\hline
\end{tabular}




\section{Table 2: Characteristics of subsamples}

This table presents means, standard deviations, number of observations, and mean differences for segments in the fiscal year prior to the divestment announcement. Panel A compares familiar and non-familiar segments, Panel B segments CEOs decide to divest and fully retain. Proxies for familiarity are CEO direct-experience and industry-experience segments. Relative size equals segment sales divided by firm sales. The size $<10 \%$ dummy indicates that segment sales are less than $10 \%$ of firm sales. The core segment dummy equals one for the largest segments within a firm year, based on sales, with the same primary two-digit SIC code as the primary two-digit SIC code of the firm. Cash flows are segments' operating profit plus depreciation and amortization. Net capital expenditures are gross capital expenditures minus depreciation and amortization. We define the cross-subsidization variable as in Ahn and Denis (2004). A segment's Tobin's $q$ represents the median industry $q$ of all Compustat firms with the same two-digit SIC code as the segment ( $q$ is the ratio of the market-to-book value of assets, as calculated in Malmendier and Tate $(2005,2008))$. Segment industry liquidity is the liquidity index at the two-digit SIC code level, as calculated in Schlingemann, Stulz, and Walkling (2002). Segment industry R\&D to assets equals R\&D expenditures of all Compustat single-segment firms with the same two-digit SIC code by the firms' beginning of year total assets. We code missing values of R\&D as zero. We define industry-adjusted variables as the segment variable minus the median of all Compustat firms with the same two-digit SIC code. Fully divested segments are segments that are completely divested and cease to be reported by firms post divestment. Aggregate transaction value is the sum of the transaction values of all divested business units within a firm year (at least one transaction value within the segment year should be available as well). Aggregate transaction value to segment sales and aggregate transaction value to segment assets are winsorized at the one- and 99-percentile. Subscripts refer to the year relative to the year in which firms announce a divestment. We truncate ratios at -1 and +1 . ***, **, and * denote that the means of familiar (divested) segments are significantly different from the means of non-familiar (retained) segments at the 1 percent, 5 percent, and 10 percent level, respectively. 
Panel A: Familiar versus non-familiar segments

\begin{tabular}{|c|c|c|c|c|c|c|c|c|c|c|c|c|}
\hline \multirow{6}{*}{$\begin{array}{l}\text { Years direct experience } \\
\text { Years since left direct experience segment } \\
\text { Years industry experience }\end{array}$} & \multicolumn{9}{|l|}{ Familiar } & \multirow{2}{*}{\multicolumn{3}{|c|}{$\begin{array}{l}\begin{array}{l}\text { Non- } \\
\text { familiar }\end{array} \\
\text { All (2) }\end{array}$}} \\
\hline & \multicolumn{3}{|c|}{ Direct experience } & \multicolumn{3}{|c|}{ Industry experience } & \multicolumn{3}{|c|}{ All (1) } & & & \\
\hline & Mean & SD. & $\mathrm{N}$ & Mean & SD. & $\mathrm{N}$ & Mean & SD. & $\mathrm{N}$ & Mean & SD. & $\mathrm{N}$ \\
\hline & 8.500 & 8.832 & 354 & - & - & 234 & 5.117 & 8.016 & 588 & - & - & 335 \\
\hline & 8.698 & 7.753 & 348 & - & - & - & - & - & - & - & . & - \\
\hline & - & - & 354 & 8.910 & 8.891 & 234 & 3.546 & 7.101 & 588 & - & - & 335 \\
\hline Sales $_{t-1}$ & 4,177 & 11,439 & 354 & 2,244 & 4,225 & 234 & 3,408 & 9,310 & 588 & $2,499 * *$ & 4,418 & 334 \\
\hline Relative size & 0.390 & 0.234 & 354 & 0.218 & 0.153 & 234 & 0.321 & 0.222 & 588 & $0.230 * * *$ & 0.199 & 334 \\
\hline Size $<10 \%$ dummy & 0.079 & 0.270 & 354 & 0.261 & 0.440 & 234 & 0.151 & 0.359 & 588 & $0.260 * * *$ & 0.440 & 334 \\
\hline Core segment & 0.404 & 0.491 & 354 & 0.103 & 0.304 & 234 & 0.284 & 0.451 & 588 & $0.140 * * *$ & 0.348 & 335 \\
\hline Cash flow $_{\mathrm{t}-1} /$ sales $_{\mathrm{t}-2}$ & 0.202 & 0.136 & 351 & 0.171 & 0.181 & 231 & 0.189 & 0.156 & 582 & $0.232 * * *$ & 0.234 & 329 \\
\hline Industry-adj. cash flow ${ }_{t-1} /$ sales $_{t-2}$ & 0.078 & 0.164 & 351 & 0.088 & 0.197 & 231 & 0.082 & 0.178 & 582 & 0.098 & 0.215 & 323 \\
\hline Capx $_{t-1} /$ sales $_{t-2}$ & 0.020 & 0.118 & 351 & 0.003 & 0.100 & 231 & 0.013 & 0.111 & 582 & 0.020 & 0.167 & 329 \\
\hline Industry-adj. capx ${ }_{t-1} /$ sales $_{t-2}$ & 0.012 & 0.116 & 351 & 0.004 & 0.098 & 231 & 0.009 & 0.109 & 582 & 0.010 & 0.171 & 323 \\
\hline Cross-subsidization & 0.004 & 0.099 & 323 & -0.005 & 0.096 & 216 & 0.000 & 0.098 & 539 & -0.013 & 0.208 & 285 \\
\hline Segment's Tobin's $q$ & 1.608 & 0.539 & 354 & 1.704 & 0.578 & 234 & 1.646 & 0.556 & 588 & 1.593 & 0.532 & 330 \\
\hline Segment's industry liquidity & 0.115 & 0.095 & 352 & 0.122 & 0.114 & 234 & 0.118 & 0.103 & 586 & $0.133 * *$ & 0.105 & 325 \\
\hline Segment's industry R\&D to assets & 0.060 & 0.061 & 303 & 0.071 & 0.058 & 204 & 0.064 & 0.060 & 507 & $0.047 * * *$ & 0.054 & 269 \\
\hline Divestment dummy & 0.367 & 0.483 & 354 & 0.346 & 0.477 & 234 & 0.359 & 0.480 & 588 & $0.421 *$ & 0.494 & 335 \\
\hline Fully divested segment dummy & 0.020 & 0.140 & 353 & 0.039 & 0.193 & 233 & 0.027 & 0.163 & 586 & $0.078 * * *$ & 0.268 & 335 \\
\hline \multicolumn{13}{|l|}{ Subsample of segments with divestments only } \\
\hline Number of divested business units & 1.485 & 0.908 & 130 & 1.185 & 0.422 & 81 & 1.370 & 0.772 & 211 & 1.504 & 1.138 & 141 \\
\hline $\begin{array}{l}\text { Aggregate transaction value of divested } \\
\text { business units }(\$-\mathrm{mln})\end{array}$ & 437.7 & 1017.3 & 72 & 481.8 & 965.6 & 46 & 454.9 & 993.5 & 118 & 453.0 & 870.6 & 90 \\
\hline Aggregate transaction value/segment sales $t-1$ & 0.388 & 0.848 & 72 & 0.566 & 1.036 & 46 & 0.458 & 0.926 & 118 & $0.708 *$ & 1.189 & 90 \\
\hline Aggregate transaction value/segment assets ${ }_{t-1}$ & 0.345 & 0.670 & 72 & 0.475 & 0.712 & 46 & 0.396 & 0.686 & 118 & 0.531 & 0.780 & 89 \\
\hline
\end{tabular}




\section{Panel B: Divested versus retained segments}

\begin{tabular}{|c|c|c|c|c|c|c|}
\hline & \multicolumn{3}{|c|}{ Divested (1) } & \multicolumn{3}{|c|}{ Retained (2) } \\
\hline & Mean & SD. & $\bar{N}$ & Mean & SD. & $\mathrm{N}$ \\
\hline Direct experience & 0.369 & 0.483 & 352 & 0.392 & 0.489 & 571 \\
\hline Industry experience & 0.230 & 0.422 & 352 & 0.268 & 0.443 & 571 \\
\hline Sales $\mathrm{t}-1$ & 3,763 & 9,778 & 352 & $2,656 *$ & 6,457 & 570 \\
\hline Sales $_{\mathrm{t}-1} /$ firm sales $_{\mathrm{t}-1}$ & 0.340 & 0.244 & 352 & $0.257 * * *$ & 0.194 & 570 \\
\hline Size $<10 \%$ dummy & 0.151 & 0.358 & 352 & $0.216 * *$ & 0.412 & 570 \\
\hline Core segment & 0.281 & 0.450 & 352 & $0.201 * * *$ & 0.401 & 571 \\
\hline Cash flow ${ }_{t-1} /$ sales $_{t-2}$ & 0.198 & 0.194 & 350 & 0.209 & 0.186 & 561 \\
\hline Industry-adj. cash flow ${ }_{\mathrm{t}-1} / \mathrm{sales}_{\mathrm{t}-2}$ & 0.074 & 0.195 & 348 & $0.096 *$ & 0.190 & 557 \\
\hline Capx ${ }_{t-1} /$ sales $_{t-2}$ & 0.016 & 0.134 & 350 & 0.015 & 0.134 & 561 \\
\hline Industry-adj. capx ${ }_{t-1} /$ sales $_{t-2}$ & 0.007 & 0.133 & 348 & 0.011 & 0.135 & 557 \\
\hline Cross-subsidization & -0.006 & 0.142 & 327 & -0.003 & 0.148 & 497 \\
\hline Segment's Tobin's $q$ & 1.637 & 0.538 & 351 & 1.621 & 0.554 & 567 \\
\hline Segment's industry liquidity & 0.127 & 0.104 & 347 & 0.121 & 0.104 & 564 \\
\hline Segment's industry R\&D to assets & 0.034 & 0.046 & 352 & 0.033 & 0.045 & 569 \\
\hline
\end{tabular}




\section{Table 3: Segment divestment binary logit regressions}

This table presents the results of binary logit regressions that explain from which type of segments firms choose to divest assets. The dependent variable takes the value of one for divested segments and zero for retained segments. We measure familiarity by means of CEOs' direct work experience in a segment. The specialist dummy equals one for CEOs in firms that have one direct-experience segment, zero otherwise. The generalist dummy equals one for CEOs familiar (at different levels, i.e., within a firm year segments are either direct-experience or industry-experience) with all the segments, zero otherwise. All other variables are self-explanatory or defined in Table 2. Subscripts refer to the year relative to the year in which firms announce a divestment. We truncate ratios at -1 and +1 . All regressions include year dummies and dummies for the number of segments (unreported). $P$-values appear in parentheses and are based on robust standard errors clustered by firm.

\begin{tabular}{|c|c|c|c|c|}
\hline & $(1)$ & (2) & (3) & (4) \\
\hline Direct experience & & $\begin{array}{l}-0.494 * * \\
(0.012)\end{array}$ & $\begin{array}{l}-0.745 * * * \\
(0.002)\end{array}$ & $\begin{array}{l}-0.614 * * * \\
(0.008)\end{array}$ \\
\hline Specialist & & & $\begin{array}{r}-0.095 \\
(0.602)\end{array}$ & \\
\hline Specialist $*$ direct experience & & & $\begin{array}{r}0.446 \\
(0.173)\end{array}$ & \\
\hline Generalist & & & & $\begin{array}{l}-0.333 \\
(0.112)\end{array}$ \\
\hline Generalist $*$ direct experience & & & & $\begin{array}{r}0.461 \\
(0.257)\end{array}$ \\
\hline Cash flow $_{t-1} /$ sales $_{t-2}$ & $\begin{array}{r}-0.576 \\
(0.217)\end{array}$ & $\begin{array}{r}-0.650 \\
(0.168)\end{array}$ & $\begin{array}{l}-0.675 \\
(0.149)\end{array}$ & $\begin{array}{l}-0.657 \\
(0.163)\end{array}$ \\
\hline Industry median cash flow ${ }_{\mathrm{t}-1} / \mathrm{sales}_{\mathrm{t}-2}$ & $\begin{array}{r}0.909 \\
(0.317)\end{array}$ & $\begin{array}{r}1.149 \\
(0.215)\end{array}$ & $\begin{array}{r}1.088 \\
(0.242)\end{array}$ & $\begin{array}{r}1.089 \\
(0.240)\end{array}$ \\
\hline Capx $_{t-1} /$ sales $_{t-2}$ & $\begin{array}{l}-1.094 * \\
(0.083)\end{array}$ & $\begin{array}{l}-1.096 * \\
(0.091)\end{array}$ & $\begin{array}{l}-1.096 * \\
(0.098)\end{array}$ & $\begin{array}{l}-1.108 * \\
(0.087)\end{array}$ \\
\hline Industry median capx $x_{t-1} /$ sales $_{t-2}$ & $\begin{array}{l}7.177 \text { *** } \\
(0.009)\end{array}$ & $\begin{array}{l}7.134 * * \\
(0.011)\end{array}$ & $\begin{array}{l}6.769 * * \\
(0.013)\end{array}$ & $\begin{array}{l}6.779 * * \\
(0.019)\end{array}$ \\
\hline Cross-subsidization & $\begin{array}{c}0.800 * \\
(0.063)\end{array}$ & $\begin{array}{c}0.878 * \\
(0.052)\end{array}$ & $\begin{array}{c}0.863 * \\
(0.060)\end{array}$ & $\begin{array}{c}0.882 * \\
(0.052)\end{array}$ \\
\hline Relative size & $\begin{array}{l}1.992 * * * \\
(0.005)\end{array}$ & $\begin{array}{l}2.273 * * * \\
(0.001)\end{array}$ & $\begin{array}{l}2.077 * * * \\
(0.005)\end{array}$ & $\begin{array}{l}2.248 * * * \\
(0.002)\end{array}$ \\
\hline Core segment & $\begin{array}{r}-0.169 \\
(0.533)\end{array}$ & $\begin{array}{r}-0.070 \\
(0.803)\end{array}$ & $\begin{array}{r}-0.060 \\
(0.832)\end{array}$ & $\begin{array}{l}-0.087 \\
(0.763)\end{array}$ \\
\hline Segment's Tobin's $q$ & $\begin{array}{r}0.126 \\
(0.464)\end{array}$ & $\begin{array}{r}0.146 \\
(0.394)\end{array}$ & $\begin{array}{r}0.133 \\
(0.442)\end{array}$ & $\begin{array}{r}0.149 \\
(0.384)\end{array}$ \\
\hline Size $<10 \%$ dummy & $\begin{array}{r}0.119 \\
(0.596)\end{array}$ & $\begin{array}{r}0.076 \\
(0.734)\end{array}$ & $\begin{array}{r}0.046 \\
(0.836)\end{array}$ & $\begin{array}{r}0.093 \\
(0.682)\end{array}$ \\
\hline Liquidity & $\begin{array}{r}1.142 \\
(0.181)\end{array}$ & $\begin{array}{r}1.074 \\
(0.204)\end{array}$ & $\begin{array}{r}1.103 \\
(0.185)\end{array}$ & $\begin{array}{r}1.121 \\
(0.188)\end{array}$ \\
\hline
\end{tabular}




\begin{tabular}{lrrrr} 
Number of observations & 823 & 823 & 823 & 823 \\
McFadden $R$-squared & $5.40 \%$ & $6.16 \%$ & $6.33 \%$ & $6.38 \%$ \\
\hline
\end{tabular}

$*$ significant at $10 \%, * *$ significant at $5 \%, * * *$ significant at $1 \%$ 


\section{Table 4: Segment divestment logit regressions: Subsamples split according to CEO tenure}

This table presents the results of binary logit regressions that explain from which type of segments firms choose to divest assets. The dependent variable takes the value of one for divested and zero for fully retained segments. Regressions (1) and (2) contain firm years with CEOs with tenure up to two years. Regression (3) contains firm years with CEOs with tenure of three or more years. We measure familiarity by means of CEOs' direct work experience in a segment. $\mathrm{COO}$ is an indicator variable that equals one for all CEOs who held the corporate executive title chief operating officer before being appointed CEO. All other variables are self-explanatory or defined in Table 2. Subscripts refer to the year relative to the year in which firms announce a divestment. We truncate ratios at -1 and +1 . All regressions include year dummies and dummies for the number of segments (unreported). $P$-values appear in parentheses and are based on robust standard errors clustered by firm.

\begin{tabular}{|c|c|c|c|}
\hline & \multicolumn{2}{|c|}{ Newly hired } & \multirow{2}{*}{$\begin{array}{c}\text { Longer tenured } \\
(3)\end{array}$} \\
\hline & (1) & (2) & \\
\hline \multirow[t]{2}{*}{ Direct experience } & -0.004 & $1.048 * *$ & $-0.722 * * *$ \\
\hline & $(0.991)$ & $(0.029)$ & $(0.002)$ \\
\hline \multirow[t]{2}{*}{$\mathrm{COO}$} & & 0.207 & \\
\hline & & $(0.564)$ & \\
\hline \multirow[t]{2}{*}{ COO $*$ Direct experience } & & $-1.505 * *$ & \\
\hline & & $(0.011)$ & \\
\hline \multirow[t]{2}{*}{ Cash flow $_{t-1} /$ sales $_{t-2}$} & -1.183 & $-1.560 * *$ & -0.341 \\
\hline & $(0.120)$ & $(0.042)$ & $(0.570)$ \\
\hline \multirow[t]{2}{*}{ Industry median cash flow ${ }_{t-1} / s^{-1 e l e s} s_{t-2}$} & 0.464 & 0.132 & 1.261 \\
\hline & $(0.787)$ & $(0.934)$ & $(0.242)$ \\
\hline \multirow[t]{2}{*}{ Capx $_{t-1} /$ sales $_{t-2}$} & $-1.723 * *$ & $-1.457 *$ & -1.535 \\
\hline & $(0.035)$ & $(0.060)$ & $(0.129)$ \\
\hline \multirow[t]{2}{*}{ Industry median capx $\mathrm{t}_{\mathrm{t}-1} / \mathrm{sales}_{\mathrm{t}-2}$} & 3.049 & 1.174 & $8.272 * * *$ \\
\hline & $(0.512)$ & $(0.808)$ & $(0.010)$ \\
\hline \multirow[t]{2}{*}{ Cross-subsidization } & 0.697 & $0.833 *$ & $1.679 *$ \\
\hline & $(0.137)$ & $(0.076)$ & $(0.090)$ \\
\hline \multirow[t]{2}{*}{ Relative size } & $2.672 * *$ & $2.670 * *$ & $2.275 * *$ \\
\hline & $(0.041)$ & $(0.042)$ & $(0.018)$ \\
\hline \multirow[t]{2}{*}{ Core segment } & -0.224 & -0.196 & -0.066 \\
\hline & $(0.622)$ & $(0.676)$ & $(0.852)$ \\
\hline \multirow[t]{2}{*}{ Segment's Tobin's $q$} & 0.194 & 0.104 & -0.014 \\
\hline & $(0.551)$ & $(0.728)$ & $(0.952)$ \\
\hline \multirow[t]{2}{*}{ Size $<10 \%$ dummy } & 0.501 & 0.573 & -0.071 \\
\hline & $(0.221)$ & $(0.166)$ & $(0.807)$ \\
\hline \multirow[t]{2}{*}{ Liquidity } & 0.546 & 0.426 & 1.574 \\
\hline & $(0.691)$ & $(0.762)$ & $(0.135)$ \\
\hline Number of observations & 281 & 279 & 542 \\
\hline McFadden $R$-squared & $6.79 \%$ & $9.18 \%$ & $8.09 \%$ \\
\hline
\end{tabular}

* significant at $10 \%, * *$ significant at $5 \%, * * *$ significant at $1 \%$ 


\section{Table 5: Segment divestment logit regressions: Information advantage of longer-tenured CEOs}

This table presents the results of binary logit regressions that explain from which type of segments firms choose to divest assets for the subsample of firm years with CEOs with three or more years of tenure. The dependent variable takes the value of one for divested segments and zero for fully retained segments. We measure familiarity by means of CEOs' direct work experience in a segment. Industry experience is an indicator variable that equals one for segments that operate in the same two-digit industry as the directexperience segment. $R \& D$ intensive industry is an indicator variable for industry $R \& D$ to assets above the sample median. A segment's industry R\&D to assets equals R\&D expenditures of all Compustat singlesegment firms with the same two-digit SIC code weighted by the firms' beginning of year total assets. We code missing values of R\&D as zero. All other variables are self-explanatory or defined in Table 2. Subscripts refer to the year relative to the year in which firms announce a divestment. We truncate ratios at -1 and +1 . All regressions include year dummies and dummies for the number of segments (unreported). $P$-values appear in parentheses and are based on robust standard errors clustered by firm.

\begin{tabular}{|c|c|c|}
\hline & $(1)$ & $(2)$ \\
\hline Direct experience & $\begin{array}{l}-0.946 * * * \\
(0.001)\end{array}$ & $\begin{array}{r}-0.341 \\
(0.293)\end{array}$ \\
\hline Industry experience & $\begin{array}{l}-0.560 * \\
(0.072)\end{array}$ & \\
\hline R\&D intensive industry & & $\begin{array}{r}0.144 \\
(0.621)\end{array}$ \\
\hline R\&D intensive industry $*$ direct experience & & $\begin{array}{l}-0.911 * * \\
(0.029)\end{array}$ \\
\hline Cash flow $_{\mathrm{t}-1} /$ sales $_{\mathrm{t}-2}$ & $\begin{array}{r}-0.462 \\
(0.446)\end{array}$ & $\begin{array}{r}-0.293 \\
(0.630)\end{array}$ \\
\hline Industry median cash flow ${ }_{\mathrm{t}-1} /$ sales $_{\mathrm{t}-2}$ & $\begin{array}{r}1.022 \\
(0.339)\end{array}$ & $\begin{array}{r}1.073 \\
(0.317)\end{array}$ \\
\hline Capx $_{t-1} /$ sales $_{t-2}$ & $\begin{array}{r}-1.493 \\
(0.155)\end{array}$ & $\begin{array}{r}-1.348 \\
(0.183)\end{array}$ \\
\hline Industry median capx $\mathrm{t}_{\mathrm{t}-1} / \mathrm{sales}_{\mathrm{t}-2}$ & $\begin{array}{l}7.707 * * \\
(0.014)\end{array}$ & $\begin{array}{l}7.832 * * \\
(0.018)\end{array}$ \\
\hline Cross-subsidization & $\begin{array}{r}1.597 \\
(0.113)\end{array}$ & $\begin{array}{r}1.446 \\
(0.152)\end{array}$ \\
\hline Relative size & $\begin{array}{l}2.202 * * \\
(0.024)\end{array}$ & $\begin{array}{l}2.579 * * * \\
(0.006)\end{array}$ \\
\hline Core segment & $\begin{array}{r}-0.056 \\
(0.878)\end{array}$ & $\begin{array}{r}-0.164 \\
(0.640)\end{array}$ \\
\hline Segment's Tobin's $q$ & $\begin{array}{r}-0.011 \\
(0.961)\end{array}$ & $\begin{array}{r}0.085 \\
(0.759)\end{array}$ \\
\hline Size $<10 \%$ dummy & $\begin{array}{r}-0.079 \\
(0.796)\end{array}$ & $\begin{array}{r}-0.004 \\
(0.990)\end{array}$ \\
\hline Liquidity & $\begin{array}{r}1.478 \\
(0.160)\end{array}$ & $\begin{array}{r}1.204 \\
(0.298)\end{array}$ \\
\hline $\begin{array}{l}\text { Number of observations } \\
\text { McFadden } R \text {-squared }\end{array}$ & $\begin{array}{r}542 \\
8.74 \% \\
\end{array}$ & $\begin{array}{r}542 \\
8.83 \% \\
\end{array}$ \\
\hline
\end{tabular}

* significant at $10 \%, * *$ significant at $5 \%, * * *$ significant at $1 \%$ 


\section{Table 6: CEO selection}

Panel A presents the results of a binary logit regression that explains from which type of segments firms choose to divest assets. Model (1) consists of the full sample of 608 divesting firm years, Model (2) the subsample of divesting firm years with CEOs with tenure up to two years, and Model (3) the subsample of divesting firm years with externally hired CEOs with tenure up to two years. The three models also include, in addition to our sample, which is selected on the basis of variation in familiarity within a firm year, firm years without the variation requirement. The dependent variable takes the value of one for divested segments and zero for fully retained segments. Table 2 defines all variables. The subscripts refer to the year relative to the year in which firms announce a divestment. We truncate ratios at -1 and +1 . All regressions include dummies for the number of segments (unreported). $P$-values appear in parentheses and are based on robust standard errors clustered by firm. In Panel B, which presents the relation between the predicted probability of a segment being divested, we use the coefficients reported in Panel A for firm years prior to CEO appointment. The panel presents the mean, median, and standard deviation of this predicted probability per level of familiarity for the subsample of firm years with variation in familiarity. We measure familiarity by means of the CEOs' work experience, split into direct-experience, industryexperience, and non-familiar segments.

Panel A: Segment divestment binary logit regression

Cash flow ${ }_{t-1} /$ sales $_{t-2}$

Industry median cash flow ${ }_{\mathrm{t}-1} / \mathrm{sales}_{\mathrm{t}-2}$

Capx $_{\mathrm{t}-1} /$ sales $_{\mathrm{t}-2}$

Industry median capx $\mathrm{x}_{\mathrm{t}-1} / \mathrm{sales}_{\mathrm{t}-2}$

Cross-subsidization

Sales ${ }_{t-1} /$ firm sales $_{t-2}$

Core segment

Segment's Tobin's $q$

Size $<10 \%$ dummy

Liquidity
(1)

Full sample

$-0.598 * *$

(0.037)

1.386 ***

(0.008)

$-0.279$

(0.468)

1.789

(0.354)

0.405

(0.326)

$1.058 * *$

(0.029)

$-0.062$

(0.755)

$0.272 * * *$

(0.005)

$-0.099$

(0.531)

0.288

(0.576)
(2)

Newly hired

$-1.083 * *$

(0.031)

0.436

(0.689)

$-0.657$

(0.220)

4.637

(0.182)

0.363

(0.338)

$1.738 * *$

(0.049)

$-0.262$

(0.446)

0.390 **

(0.032)

0.071

(0.812)

0.341

(0.686)
(3)

Newly and externally hired

$-1.533$

(0.137)

$-1.622$

$(0.390)$

$-0.606$

$(0.501)$

7.222

(0.454)

1.541

(0.407)

1.288

$(0.451)$

$-0.497$

(0.505)

$0.787 * *$

$(0.027)$

$-0.212$

$(0.725)$

$-0.081$

(0.954)

Number of observations

1805

578

180

McFadden $R$-squared

$4.12 \%$

$9.16 \%$

* significant at $10 \%, * *$ significant at $5 \%$, *** significant at $1 \%$ 
Panel B: Predicted probability of divestment per type of familiarity

\begin{tabular}{|c|c|c|c|c|c|}
\hline \multicolumn{2}{|c|}{ Direct exp. } & \multirow{2}{*}{$\begin{array}{r}\text { Industry exp. } \\
\text { (2) }\end{array}$} & \multirow{2}{*}{$\begin{array}{r}\text { Non-familiar } \\
\text { (3) } \\
\end{array}$} & \multicolumn{2}{|c|}{$P$-value of differences } \\
\hline & (1) & & & (1) - (3) & $(2)-(3)$ \\
\hline $\mathrm{N}$ & 91 & 54 & 91 & & \\
\hline \multicolumn{6}{|c|}{ Predicted probabilities based on the coefficients in Model (1) } \\
\hline Mean & 0.415 & 0.341 & 0.370 & 0.003 & 0.040 \\
\hline Median & 0.400 & 0.331 & 0.353 & 0.001 & 0.116 \\
\hline SD. & 0.104 & 0.069 & 0.100 & & \\
\hline \multicolumn{6}{|c|}{ Predicted probabilities based on the coefficients in Model (2) } \\
\hline Mean & 0.411 & 0.348 & 0.370 & 0.014 & 0.122 \\
\hline Median & 0.401 & 0.341 & 0.354 & 0.018 & 0.217 \\
\hline SD. & 0.116 & 0.068 & 0.106 & & \\
\hline \multicolumn{6}{|c|}{ Predicted probabilities based on the coefficients in Model (3) } \\
\hline Mean & 0.351 & 0.311 & 0.332 & 0.453 & 0.477 \\
\hline Median & 0.371 & 0.332 & 0.337 & 0.313 & 0.584 \\
\hline SD. & 0.160 & 0.158 & 0.179 & & \\
\hline
\end{tabular}




\section{Table 7: Analysis of CARs to divestment announcements}

Panel A presents the means, standard deviations, and mean differences of the cumulative abnormal returns over days -1 to +1 relative to a divestment announcement. Panel B presents the results of ordinary least squares regressions of three-day CARs to divestment announcements. We estimate abnormal returns by means of the market model with an estimation window running from day -160 to day -41 relative to the announcement date. Abnormal returns are winsorized at the one- and 99-percentile values. We measure familiarity by means of CEOs' direct and industry experience in a segment. Newly hired CEOs are CEOs with tenure up to two years, longer-tenured CEOs, CEOs with tenure of three or more years. R\&D intensive industries are industries with $\mathrm{R} \& \mathrm{D}$ to assets above the sample median. A segment's industry R\&D to assets equals R\&D expenditures of all Compustat single-segment firms with the same two-digit SIC code weighted by the firms' beginning of year total assets. We code missing values of R\&D as zero. Relative transaction size is the transaction value divided by the book value of a firm's total assets. We calculate firms' industry-adjusted capital expenditures, leverage, and cash as the firm variable minus the median of all Compustat firms with the same two-digit SIC code. All other variables are defined in Tables 1 and 2. $P$-values appear in parentheses and are based on Huber-White standard errors.

\section{Panel A: CARs in familiarity and tenure subsamples}

\begin{tabular}{|c|c|c|c|c|}
\hline & & $\begin{array}{c}\text { Direct experience } \\
\text { (1) }\end{array}$ & $\begin{array}{c}\text { Industry experience } \\
\text { (2) }\end{array}$ & $\begin{array}{c}\text { Non-familiar } \\
(3)\end{array}$ \\
\hline \multirow[t]{3}{*}{ Full sample } & Mean & $0.67 \% * *$ & $0.33 \%$ & $0.32 \%$ \\
\hline & St.dev. & $(3.86 \%)$ & $(4.68 \%)$ & $(3.76 \%)$ \\
\hline & $\mathrm{N}$ & 168 & 84 & 186 \\
\hline \multirow{3}{*}{$\begin{array}{l}\text { Sample with available } \\
\text { information }\end{array}$} & Mean & $1.27 \% * * *$ & $0.22 \%$ & $0.34 \%$ \\
\hline & St.dev. & $(3.94 \%)$ & $(4.64 \%)$ & $(4.42 \%)$ \\
\hline & $\mathrm{N}$ & 76 & 40 & 92 \\
\hline \multicolumn{5}{|l|}{ Longer-tenured CEOs } \\
\hline \multirow[t]{3}{*}{ Full sample } & Mean & $0.78 \% * *$ & $0.72 \%$ & $0.27 \%$ \\
\hline & St.dev. & $(3.66 \%)$ & $(4.64 \%)$ & $(3.86 \%)$ \\
\hline & $\mathrm{N}$ & 97 & 46 & 135 \\
\hline \multirow{3}{*}{$\begin{array}{l}\text { Sample with available } \\
\text { information }\end{array}$} & Mean & $1.62 \% * * *$ & $0.42 \%$ & $0.18 \%$ \\
\hline & St.dev. & $(3.86 \%)$ & $(3.49 \%)$ & $(4.50 \%)$ \\
\hline & $\mathrm{N}$ & 43 & 23 & 73 \\
\hline \multicolumn{5}{|l|}{ Newly hired CEOs } \\
\hline \multirow[t]{3}{*}{ Full sample } & Mean & $0.50 \%$ & $-0.14 \%$ & $0.43 \%$ \\
\hline & St.dev. & $(4.15 \%)$ & $(4.75 \%)$ & $(3.52 \%)$ \\
\hline & $\mathrm{N}$ & 71 & 38 & 51 \\
\hline \multirow{3}{*}{$\begin{array}{l}\text { Sample with available } \\
\text { information }\end{array}$} & Mean & $0.80 \%$ & $-0.05 \%$ & $0.96 \%$ \\
\hline & St.dev. & $(4.05 \%)$ & $(5.96 \%)$ & $(4.17 \%)$ \\
\hline & $\mathrm{N}$ & 33 & 17 & 19 \\
\hline
\end{tabular}


Panel B: Regression analysis explaining CARs

\begin{tabular}{|c|c|c|c|c|c|}
\hline & $(1)$ & $(2)$ & $(3)$ & $(4)$ & $(5)$ \\
\hline Direct experience & $\begin{array}{l}0.012 * * \\
(0.044)\end{array}$ & $\begin{array}{r}0.012 \\
(0.128)\end{array}$ & & & \\
\hline Direct experience, newly hired & & & $\begin{array}{r}0.008 \\
(0.373)\end{array}$ & $\begin{array}{r}0.008 \\
(0.349)\end{array}$ & $\begin{array}{r}0.008 \\
(0.368)\end{array}$ \\
\hline Direct experience, longer-tenured & & & $\begin{array}{r}0.016 \\
(0.115)\end{array}$ & $\begin{array}{r}0.017 \\
(0.118)\end{array}$ & \\
\hline Direct experience, longer-tenured, $R \& D$ intensive & & & & & $\begin{array}{r}0.006 \\
(0.696)\end{array}$ \\
\hline Direct experience, longer-tenured, not $R \& D$ intensive & & & & & $\begin{array}{l}0.024 * * \\
(0.020)\end{array}$ \\
\hline Industry experience & & & & $\begin{array}{r}0.002 \\
(0.807)\end{array}$ & \\
\hline Excess value & & $\begin{array}{r}0.000 \\
(0.974)\end{array}$ & $\begin{array}{l}-0.001 \\
(0.952)\end{array}$ & $\begin{array}{r}-0.000 \\
(0.959)\end{array}$ & $\begin{array}{l}-0.002 \\
(0.842)\end{array}$ \\
\hline Core segment & & $\begin{array}{r}0.002 \\
(0.781)\end{array}$ & $\begin{array}{r}0.001 \\
(0.938)\end{array}$ & $\begin{array}{r}0.001 \\
(0.947)\end{array}$ & $\begin{array}{r}0.001 \\
(0.948)\end{array}$ \\
\hline Relative transaction size & $\begin{array}{l}0.107^{* *} \\
(0.012)\end{array}$ & $\begin{array}{l}0.112 * * \\
(0.015)\end{array}$ & $\begin{array}{l}0.109^{* *} \\
(0.018)\end{array}$ & $\begin{array}{l}0.110 * * \\
(0.017)\end{array}$ & $\begin{array}{l}0.110^{* *} \\
(0.017)\end{array}$ \\
\hline Tobin's $q$ & $\begin{array}{l}-0.004 * \\
(0.089)\end{array}$ & $\begin{array}{r}-0.004 \\
(0.204)\end{array}$ & $\begin{array}{r}-0.004 \\
(0.199)\end{array}$ & $\begin{array}{r}-0.004 \\
(0.199)\end{array}$ & $\begin{array}{l}-0.003 \\
(0.339)\end{array}$ \\
\hline Industry-adj. capx $\mathrm{t}_{\mathrm{t}-1} / \mathrm{sales}_{\mathrm{t}-2}$ & $\begin{array}{r}0.131 \\
(0.185)\end{array}$ & $\begin{array}{r}0.146 \\
(0.290)\end{array}$ & $\begin{array}{r}0.147 \\
(0.297)\end{array}$ & $\begin{array}{r}0.148 \\
(0.299)\end{array}$ & $\begin{array}{r}0.168 \\
(0.233)\end{array}$ \\
\hline Industry-adj. leverage & $\begin{array}{r}0.023 \\
(0.250)\end{array}$ & $\begin{array}{r}0.025 \\
(0.280)\end{array}$ & $\begin{array}{r}0.022 \\
(0.325)\end{array}$ & $\begin{array}{r}0.022 \\
(0.328)\end{array}$ & $\begin{array}{r}0.024 \\
(0.286)\end{array}$ \\
\hline Industry-adj, cash ${ }_{t-1} /$ sales $_{t-2}$ & $\begin{array}{r}0.019 \\
(0.540)\end{array}$ & $\begin{array}{r}0.018 \\
(0.686)\end{array}$ & $\begin{array}{r}0.020 \\
(0.644)\end{array}$ & $\begin{array}{r}0.021 \\
(0.633)\end{array}$ & $\begin{array}{r}0.010 \\
(0.816)\end{array}$ \\
\hline Percentage of stock owned & $\begin{array}{l}-0.075 * \\
(0.080)\end{array}$ & $\begin{array}{l}-0.076 * \\
(0.092)\end{array}$ & $\begin{array}{l}-0.074 * \\
(0.095)\end{array}$ & $\begin{array}{r}-0.072 \\
(0.106)\end{array}$ & $\begin{array}{l}-0.074 * \\
(0.099)\end{array}$ \\
\hline Intercept & $\begin{array}{r}0.004 \\
(0.615)\end{array}$ & $\begin{array}{r}0.002 \\
(0.774)\end{array}$ & $\begin{array}{r}0.003 \\
(0.679)\end{array}$ & $\begin{array}{r}0.002 \\
(0.774)\end{array}$ & $\begin{array}{r}0.001 \\
(0.934)\end{array}$ \\
\hline Number of observations & 208 & 187 & 187 & 187 & 187 \\
\hline Adjusted R-squared & $7.3 \%$ & $6.2 \%$ & $6.0 \%$ & $5.5 \%$ & $6.2 \%$ \\
\hline
\end{tabular}

* significant at $10 \%, * *$ significant at $5 \%, * * *$ significant at $1 \%$ 